\begin{tabular}{|c|c|c|}
\hline $\begin{array}{l}\text { APR } 281995 \\
70) \text { St (36) }\end{array}$ & ENGINEERING DATA TRANSMITTAL & 1. EDT 602398 \\
\hline
\end{tabular}

\begin{tabular}{|l|l|}
\hline $\begin{array}{l}\text { 2. To: (Receiving organization) } \\
\text { Distribution }\end{array}$ & $\begin{array}{l}\text { 3. From: (originating Organization) } \\
\text { Waste Tank Process } \\
\text { Engineering }\end{array}$ \\
\hline $\begin{array}{l}\text { 5. Proj./Prog./Dept./Div。: } \\
\text { W236-A (MWTF). }\end{array}$ & $\begin{array}{l}\text { 6. Cog. Engr.: } \\
\text { Richard G. Brown }\end{array}$ \\
\hline
\end{tabular}

8. Originator Remarks:

For review. Please send your comments (or "no comment") using an RCR by $3 / 16 / 95$. Electronic copies appreciated.

\begin{tabular}{|c|c|}
\hline $\begin{array}{l}\text { 4. Related EDT No.: } \\
\text { NA }\end{array}$ \\
\hline $\begin{array}{c}\text { 7. Purchase Order No.: } \\
\text { NA }\end{array}$ \\
\hline
\end{tabular}

9. Equip./Component No.:

\begin{tabular}{|c|} 
NA \\
\hline 10. System/Bldg./Facility:
\end{tabular}

NA

11. Receiver Remarks:

12. Major Assm. Dwg. No.:

NA

13. Permit/Permit Application No.: NA

14. Required Response Date:

March 16, 1995

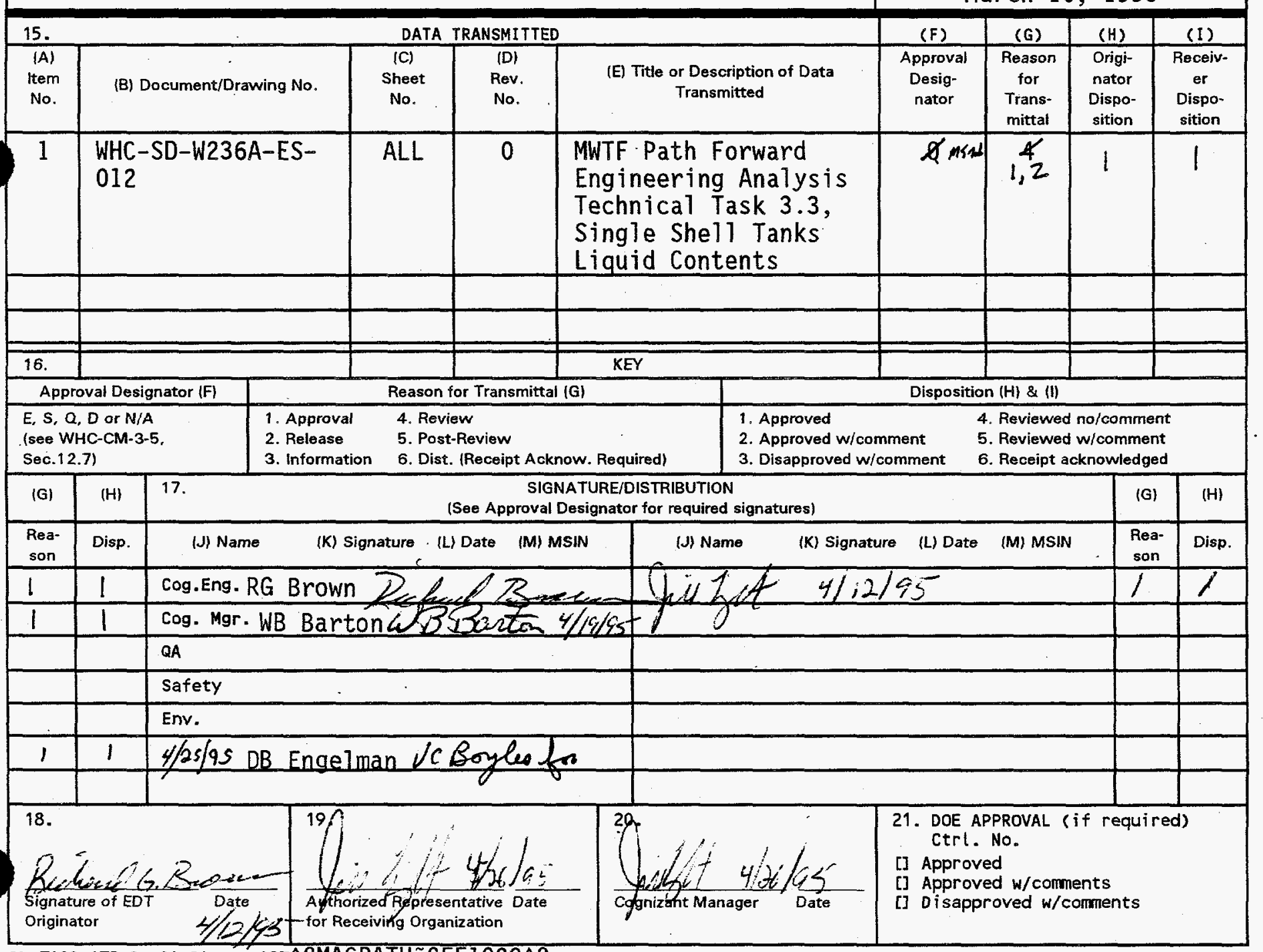

BD-7400-172-2 (04/94) GEF097^GMACPATH ${ }^{\sim}$ GEF $1000^{\wedge} \mathrm{G}$ 


\section{INSTRUCTIONS FOR COMPLETION OF THE ENGINEERING DATA TRANSMITTAL}

(USE BLACK INK OR TYPE)

\begin{tabular}{|c|c|}
\hline BLOCK & TITLE \\
\hline$(1)^{*}$ & EDT \\
\hline (2) & To: (Receiving Organization) \\
\hline 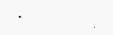 & \\
\hline (3) & From: 1Originating Organization \\
\hline (4) & Related EDT No. \\
\hline$(5)^{*}$ & Proj./Prog./Dept./Div. \\
\hline$(6)^{*}$ & Cognizant Engineer \\
\hline (7) & Purchase Order No. \\
\hline$(8) *$ & Originator Remarks \\
\hline (9) & Equipment/Component No. \\
\hline (10). & System/Bidg./Facility \\
\hline$(11)$ & Receiver Remarks \\
\hline (12) & Major Assm. Dwg. No. \\
\hline (13) & Permit/Permit Applicetion No. \\
\hline (14) & Required Response Date \\
\hline
\end{tabular}

(15)* Data Transmitted
(A) Item Number
(B) * Document/Drawing No.
(C) * Sheet No.
(D) Rev. No.
(E) Title or Description of Data Transmitted
(F)* Impact Level
(G) Reason for Transmittal
(H) Originator Disposition
(I) Receiver Disposition

(16) Key

(17) Signature/Distribution
(G) Reason
(H) Disposition
(J) Name
$(K)^{*}$ Signature
(L)* Date
(M)* MSIN

(18) Signature of EDT Originator

(19) Authorized Representative for Receiving Organization

(20) * Cognizant Manager

(21)* DOE Approval
- Pre-assigned EDT number.

- Enter the individual's name, title of the organization, or entity (0.g., Distribution) that the EDT is being transmitted to.

- Enter the title of the organization originating and transmitting the EDT.

- Enter EDT numbers which relate to the data being transmitted.

- Enter the Project/Program/Depertment/Division title or Project/Program ecronym or Project Number, Work Order Number or Organization Code.

- Enter the name of the individual identified as being responsible for coordinating disposition of the EDT.

- Enter related Purchase Order (P.O.) Number, if available.

- Enter special or additional comments concerning transmittal, or "Key" retrieval words may be entered.

- Enter equipment/component number of affected item, if appropriate.

- Enter appropriate system, building or facility number, if appropriate.

- Enter special or additional comments concerning transmittal.

- Enter applicable drawing number of major assembly, if appropriate.

- Enter applicable permit or permit application number, if appropriate.

- Enter the date a response is required from individuals identified in Block 17 (Signature/Distribution).

- Enter sequential number, beginning with 1, of the information listed on EDT.

- Enter the unique identification number assigned to the document or drawing being transmitted.

- Enter the sheet number of the information being transmitted. If no sheot number, leave blank.

- Enter the revision number of the information being transmitted. If no revision number, leave blank.

- Enter the title of the document or drawing or a brief description of the subject if no title is identified.

- Enter the appropriate Impact Level (Block 15). Also, indicate the appropriate approvals for each item listed, i.e., SQ, ESQ, etc. Use NA for non-engineering documents.

- Enter the appropriate code to identify the purpose of the data transmittal (see Block 16).

- Enter the appropriate disposition code (see Block 16).

- Enter the appropriate disposition code (see Block 16).

- Number codes used in completion of Blocks $15(\mathrm{G}),(H)$, and (I), and $17(\mathrm{G}),(H)$ (Signature/Distribution).

- Enter the code of the resson for trensmittal (Block 16).

- Enter the code for the disposition (Block 16).

- Enter the signature of the individual completing the Disposition $17(\mathrm{H})$ and the Transmittal.

- Obtain appropriate signature(s).

- Enter date signature is obtained.

- Enter MSIN. Note: If Distribution Sheet is used, show entire distribution lincluding that indicated on Page 1 of the EDT) on the Distribution Sheet.

- Enter the signature and date of the individual originating the EDT lentered prior to transmittal to Receiving Organization). If the EDT originator is the cognizant engineer, sign both Blocks 17 and 18.

- Enter the signature and date of the individual identified by the Receiving Organization as authorized to approve disposition of the EDT and acceptance of the data transmitted, as applicable.

- Enter the signature and date of the cognizant manager. (This signature is authorization for release.)

- Enter DOE approval (if required) by letter number and indicate DOE action.

*Asterisk denote the required minimum items check by Configuration Documentation prior to release; these are the minimum release requirements. 


\section{DISCLAIMER}

Portions of this document may be illegible in electronic image products. Images are produced from the best available original document. 
2. Title

Multi-Function Waste Tank Facility Path Forward Engineering Analysis Technical Task 3.3, SingleShell Tank Liquid Contents

5. Key Words

MWTF,TANKS, PATH FORWARD, W23GA
3. Number

WHC-SD-W236A-ES-012

4. Rev No.

0

6. Author

Name: R. G. Brown/R. W. Mattichak Rimaterhal

Organization/Charge Code

7. Abstract

8.

RELEASE STAMP

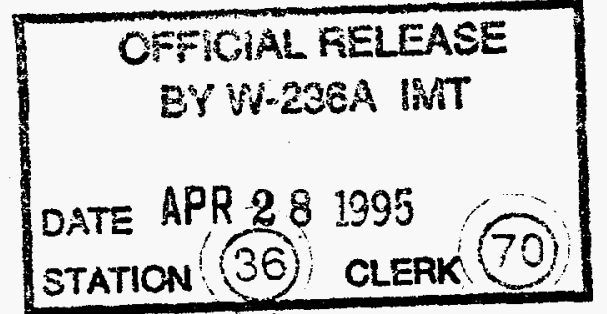




\section{RELEASE AUTHORIZATION}

Document Number: WHC-SD-W236A-ES-012, Rev. 0

Multi-Function Waste Tank Facility Path Forward

Engineering Analys is Technical Task 3.3, Single-

Shell Tank Liquid Contents

Release Date: $\quad$ Apri1 28, 1995

\section{This document was reviewed following the procedures described in WHC-CM-3-4 and is:}

\section{APPROVED FOR PUBLIC RELEASE}

WHC Information Release Administration Specialist:

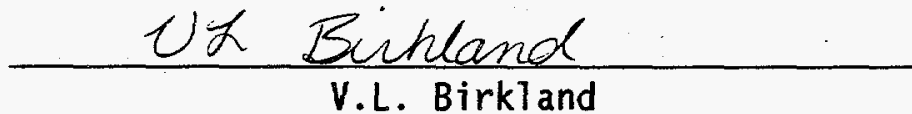

Apri门 28, 1995

\section{V.L. BirkTand}

TRADEMARK DISCLAIMER. Reference herein to any specific comercial product, process, or service by trade name, tradenark, manufacturer, or otherwise, does not necessarily constitute or imply its endorsement, recommendation, or favoring by the United States Goverrment or any agency thereof or $i$ ts contractors or subcontractors.

This report has been reproduced from the best available copy. Available in paper copy and microfiche. Printed in the United States of America. Available to the U.S. Department of Energy and its contractors from:

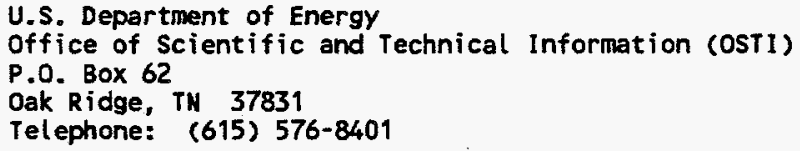

\section{U.S. Department of Cormerce} National Technical Information Service (NTIS) 5285 Port Royal Road

Springfield, VA 22161

Telephone: (703) $487-4650$ 
WHC-SD-W236A-ES-012

Revision 0

\title{
MULTI-FUNCTION WASTE TANK FACILITY PATH FORWARD ENGINEERING ANALYSIS TECHNICAL TASK 3.3, SINGLE-SHELL TANK LIQUID CONTENTS
}

\author{
R. G. Brown \\ R. W. Mattichak \\ Westinghouse Hanford Company \\ Richland, Washington
}

\section{DISCLAIMER}

This report was prepared as an account of work sponsored by an agency of the United States Government. Neither the United States Government nor any agency thereof, nor any of their employees, makes any warranty, express or implied, or assumes any legal liability or responsibility for the accuracy, completeness, or usefulness of any information, apparatus, product, or process disclosed, or represents that its use would not infringe privately owned rights. Reference herein to any specific commercial product, process, or service by trade name, trademark, manufacturer, or otherwise does not necessarily constitute or imply its endorsement, recommendation, or favoring by the United States Government or any agency thereof. The views and opinions of authors expressed herein do not necessarily state or reflect those of the United States Government or any agency thereof. 
WHC-SD-W236A-ES-012

Revision 0

This page intentionally left blank. 
WHC-SD-W236A-ES-012

Revision 0

\section{EXECUTIVE SUMMARY}

The purpose of this study is to determine the quantities of liquid waste remaining in the unstabilized single-shell tanks (SST) and to determine the quantities of flush water produced from flushing salt well lines and transfer lines for interim double-shell tank (DST) storage.

To provide an accurate estimate of the waste liquid remaining in the salt cake and sludge waste tanks, a separate "projected porosity value" (see Glossary for definition) was calculated for the salt cake volume and the sludge volume. Recent waste characterization reports ${ }^{1,2,3}$ compiled the historical data that were used for the salt cake, sludge, and supernatant volumes remaining within the waste tanks. A total of 25 salt cake tanks and 6 sludge tanks were selected to calculate the projected porosity values. The resultant average projected porosity value is $61 \%$ for salt cake tanks and $16 \%$ for sludge tanks.

It is emphasized that this study calculated the projected porosity value which should be used for projecting the quantities of total liquids that are remaining within the unstabilized waste tanks. These quantities include interstitial liquid plus the unidentified 1iquid (supernatant) that may be

${ }^{1}$ Gaddis, L. A., and W. W. Pickett, 1994, Historical Tank Content Estimate for the Southwest Quadrant of the Hanford 200 West Areas, WHC-SD-WM-ER-352, Rev. 0, Westinghouse Hanford Company, Richland, Washington.

${ }^{2}$ Gaddis, L. A., and W. W. Pickett, 1994, Historical Tank Content Estimate for the Northeast Quadrant of the Hanford 200 East Areas, WHC-SD-WM-ER-349, Rev. 0, Westinghouse Hanford Company, Richland, Washington.

${ }^{3}$ Gaddis, L. A., and W. W. Pickett, 1995, Historical Tank Content Estimate for the Northwest Quadrant of the Hanford 200 West Area, WHC-SD-WM-ER-351, Rev. 0, Westinghouse Hanford Company, Richland, Washington. 
contained as a hidden pocket and/or layer between the salt cake layers, and has not been identified prior to salt well pumping. This is different from the 'uniform' salt cake porosity that is calculated after pumping has been initiated and does not include the supernatant liquids that are found. It accounts for the supernatant liquid separately. However, for predicting the total liquid to be pumped from the tank, both the interstitial liquid reflected in the salt cake true uniform porosity plus the hidden pockets of supernatant must be accounted for.

There has not been significant pumping experience with sludge tanks. Previous studies have suggested that a 'true' sludge material would be unpumpable. Pumping of tanks containing sludge has shown that some materials defined as sludge do have interstitial liquid flow properties similar to salt cake. However, large pockets or layers of hidden supernatant are not anticipated.

Results from this study indicate the following.

- Salt well pumping will produce 6.0 million gallons (Mgal) of waste liquid for interim storage in the DSTs. This is an increase of 1.0 Mgal of liquid waste over the January 13,1995 , position letter" projections using a $45 \%$ "uniform" salt cake porosity value and an increase of $1.8 \mathrm{Mgal}$ over projections in

*Alumkal, W. T., 1995, Multi-Function Waste Tank Facility-Decision Paper (Letter 9550111 to T. R. Sheridan, U.S. Department of EnergyHeadquarters), Westinghouse Hanford Company, Richland, Washington. 
WHC-SD-W236A-ES-012

Revision 0

WHC-SD-WM-ER-029, Operational Waste Volume Projection ${ }^{\star}$ using a $35 \%$ 'uniform' salt cake porosity value.

- Flushing of the salt well lines and transfer lines will generate an additional $1.6 \mathrm{Mgal}$ of water that will require interim storage in the DSTs until waste volume reduction through the evaporator can be accomplished.

The salt well pumping and flush water will eventually be evaporated, which will reduce the volume of liquid for DST storage for final disposal. For volume reductions, see WHC-SD-WM-TI-690, Waste Volume Reduction Factors for Potential 242-A Evaporator Feed (Sederburg 1995).**

This study uses the actual total liquids removed and the field-calculated interstitial liquid remaining to be pumped from the actual data records for the waste salt cake and sludge within the SSTs that have been, or are being, pumped. The projected porosity value is defined as the volume percentage of total liquid (includes hidden pockets and/or layers of supernatant) within the total bulk salt cake volume, excluding the capillary held region and identified supernatant. The accuracy of the quantity of liquids to be pumped depends on an accurate determination of quantities and properties of the salt cake and sludge in the SSTs. The database used for this study relied on the actual data that were available; however, the data for the pumping of the

"Strode, J. N., 1994, Operational Waste Volume Projection, WHC-SD-WM-ER-029, Rev. 20, Westinghouse Hanford Company, Richland, Washington.

**Sederburg, J. P., 1995, Waste Volume Reduction Factors for Potential 242-A Evaporator Feed, WHC-SD-WM-TI-690, Rev. 0, Westinghouse Hanford Company, Richland, Washington. 
stabilized tanks (1980's) were not necessarily complete so assumptions were necessary. The recent pumping data obtained for the current pumping operations are more complete and support the $61 \%$ projected porosity value for salt cake tanks.

The salt cake database had varying salt cake porosities that ranged from $30 \%$ to $100 \%$, with a $19.6 \%$ standard deviation. However, the database was not a normal distribution and the confidence of any one tank having a $61 \%$ salt cake porosity would be low.

The sludge database consisted of six tanks with total pumping of $71 \mathrm{kgal}$ of 1 iquids. The porosity values range from $11 \%$ to $23 \%$ with a standard deviation of $4.5 \%$. Of the remaining liquids to be removed from the SSTs, the sludge tanks will contribute just over 5\% (0.3 Mgal).

Inaccuracies in the solids measurements and the inability to accurately estimate supernate volumes contribute to the spread of the data and the high porosities exhibited by the salt cake database. The same range can be expected for the remaining tanks that require stabilization.

The flush water projection was based on the procedural requirements for the flushing of the salt well pumping equipment and system plus the transfer lines. This includes the transfer lines from the double-contained receiver tank to the DST for storage. The flush water projection did not include any transfer flush water between the 200 East and 200 West Area Tank Farms. 
WHC-SD-W236A-ES-012

Revision 0

CONTENTS

1.0 INTRODUCTION . . . . . . . . . . . . . . . . . . . . . 1-1

1.1 HISTORICAL BACKGROUND . . . . . . . . . . . . . . . . 1-1

1.2 BACKGROUND ................... . . 1-2

1.3 PURPOSE AND NEED .. . . . . . . . . . . . . . . . 1-5

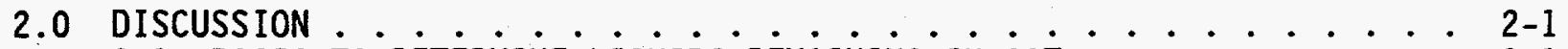

2.1 BASIS TO DETERMINE LIQUIDS REMAINING IN SSTS . . . . . . . . . 2-1

2.1.1 Assumptions Necessary for Data Interpretation . . . . . 2-3

2.1.2 Determination of Salt Cake and STudge Porosities . . . . 2-4

2.1.3 PLR . . . . . . . . . . . . . . . 2-5

2.2 BASIS TO DETERMINE FLUSH WATER REQUIREMENTS . . . . . . . . . 2-7

2.2.1 Flush Water Assumptions . . . . . . . . . . . . . 2-7

2.3 SEGREGATION OF COMPLEX WASTE . . . . . . . . . . . . 2-7

3.0 RESULTS AND CONCLUSIONS . . . . . . . . . . . . . . . . . 3-1

3.1 RESULTS . . . . . . . . . . . . . . . . . 3-1

3.2 CONCLUSIONS ....................... 3-1

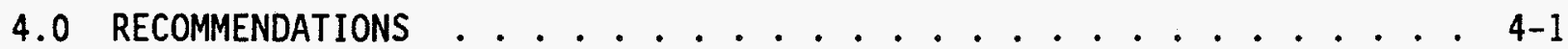

5.0 REFERENCES ......................... 5-1

6.0 BIBLIOGRAPHY . . . . . . . . . . . . . . . . . . . . . . . .

7.0 GLOSSARY . . . . . . . . . . . . . . . . . . . GL-1

APPENDIXES

A POROSITY CALCULATIONS . . . . . . . . . . . . . . . . . . A-1

B SINGLE-SHELl TANK POROSITY DATABASE . . . . . . . . . . . . . . . B-1

C POROSITY PROJECTION COMPARISON . . . . . . . . . . . . . . . . c-1

D UNSTABILIZED SINGLE-SHELL TANK LIQUID INVENTORY . . . . . . . . . . . D-I

E BREAKDOWN OF COMPLEX/NONCOMPLEX UNSTABILIZED SINGLE-SHELL TANKS . . . E-1 
WHC-SD-W236A-ES-012

Revision 0

\section{LIST OF FIGURES}

1-1 Porosity Values for Stabilized Single-Shell Salt Cake Tanks . . . . 1-3

1-2 Porosity Values for Stabilized Single-Shell Sludge Tanks . . . . . 1-4

2-1 Salt Cake Porosity. . . . . . . . . . . . . 2-2

2-2 Liquid Waste Remaining in the Single-Shell Tanks . . . . . . 2-6 


\section{MULTI-FUNCTION WASTE TANK FACILITY PATH FORWARD ENGINEERING ANALYSIS TECHNICAL TASK 3.3, SINGLE-SHELL TANK LIQUID CONTENTS}

\subsection{INTRODUCTION}

\subsection{HISTORICAL BACKGROUND}

Single-shell tanks (SST) were constructed between 1943 and 1964 to store liquid and solid wastes generated as a result of plutonium production and separation operations at the Hanford Site. Until 1980, the liquid radioactive chemical waste produced from defense activities was pumped initially to 149 SSTs for storage. In 1978, the interim stabilization program was implemented, and by 1981, the 149 SSTs were declared out of service and newly generated waste was contained in the double-shell tanks (DST). The purpose of the ongoing interim stabilization program is to remove pumpable liquid from the SSTs to minimize the risk to the environment in the event of a tank leak (Klem 1986).

In the late 1950's and throughout the 1960's, one method, or a combination of methods, was applied to leaking tanks to reduce the effect of the leaks: (1) the tank was isolated to prevent any further addition of waste to the tank, (2) diatomaceous earth was added to absorb the liquid waste, (3) sludge was air cooled, or (4) a combination of isolation and addition of diatomaceous earth was used. In the 1970's, the environmental impact of tank leaks was reduced by transferring supernatant to an evaporator where a large fraction of the water was removed. The remaining waste was returned to the tanks as saturated slurry which formed salt cake (Forney 1989). Generally, two types of solids exist in the SSTs: sludge and salt cake. sludge results from the neutralization of chemical separation wastes, and salt cake results from thermal evaporation of aged chemicals and miscellaneous wastes (DeWeese 1988). For SSTs containing both types of solids, the salt cake layer is generally above the sludge. Liquid is present in SSTs as free-standing supernatant and/or as interstitial liquid existing in the void spaces of solid wastes.

The supernatant and interstitial liquid are removed from the SSTs by salt well pumping. In this method, the liquid is jet pumped through a salt well casing installed in the tanks. Salt well pumping continues until either a major pumping failure occurs and the tank meets the interim stabilization criteria, or the pumping rate decreases to $0.05 \mathrm{gpm}$. After the salt well liquor has been removed and has met the tank stabilization requirements, the tank is physically isolated to minimize the possibility of any future intrusion of liquid into the tank.

The liquid waste pumped from the SSTs is collected in a double-contained receiver tank (DCRT) and sent to a DST for interim storage. The liquid is ultimately sent to the evaporator for waste volume minimization and the resulting slurry from the evaporator is sent to DSTs for interim storage pending final disposal. 
Since the interim stabilization process began in 1978, 108 SSTs have been classified as interim stabilized (as of March 1995). The bulk of the liquid remaining in the 41 unstabilized SSTs is interstitial liquid. The term 'porosity' (see Glossary for definition) is used to determine the volume fraction of drainable interstitial liquid in the waste solids. It has not in past practice included pockets or layers of liquid existing in different locations within the salt cake. An accurate porosity estimation method is needed to predict the volume of liquid waste remaining in the SSTs still requiring stabilization. The SST liquid volume and the volume of flush water required to transfer the waste are needed to project the DST storage capacity required to support the stabilization program.

\subsection{BACKGROUND}

Current waste volume projections assume a $35 \%$ salt cake porosity for a baseline case and a $45 \%$ salt cake porosity for an upper planning case in determining the interstitial liquid volumes (Strode 1994). Both cases use a $12.5 \%$ porosity for the sludge. By using $35 \%$ and $45 \%$ salt cake porosity waste volume projections, it is predicted that 4.2 and 5.0 million gallons (Mgal), respectively, of pumpable liquid waste remain in the SSTs.

Studies have been performed in the past to derive a 'uniform' salt cake porosity that could be used to predict the volume of interstitial liquid in the SSTs. Early laboratory experiments on synthetic salt cakes estimated a porosity between 30\% and 35\% (Handy 1975, Strachan 1975, Metz 1976). The porosity values used from these studies tend to give low estimates of the pumpable interstitial liquid. This is partly due to the lack of in-tank solids data available at the time, and because the synthetic salt cakes used in the laboratory experiments were of uniform density and did not have any liquid pockets or layers in them, which have been found to exist in actual salt cakes once pumping has begun. Interstitial liquid volume predictions are based on the volume as well as the porosity of the salt cake and sludge. Because of the inability to characterize the solids in the tank bottoms and the poor record keeping of tank transfers, it was extremely difficult to determine the tank contents (Anderson and Mudd 1990). Therefore, earlier predictions of pumpable waste remaining in the SSTs were low due to poor quality of available data.

Realizing this problem of inaccurate data, the Characterization Program recently compiled all known historical data relating to the Hanford Site 200 Area tanks. This compilation of data is represented in the waste characterization reports entitled Historical Tank Content Estimate for the Southwest Quadrant of the Hanford 200 West Areas (Gaddis and Pickett 1994a), Historical Tank Content Estimate for the Northeast Quadrant of the Hanford 200 East Areas (Gaddis and Pickett 1994b), and Historica7. Tank Content Estimate for the Northwest Quadrant of the Hanford 200 West Area (Gaddis and Pickett 1995). The information given in the waste characterization reports is considered to be the most accurate depiction of SST solid contents. Using this information to correct the solid volume data used for previous stabilization efforts of jet-pumped salt cake and sludge tanks, along with stabilization records of liquid waste (supernate and interstitial) removed from the tanks, provides a more accurate porosity value of the salt cake and sludge (Figures 1-1 and 1-2). 
Figure 1-1. Porosity Values for Stabilized Single-Shell Salt Cake Tanks.
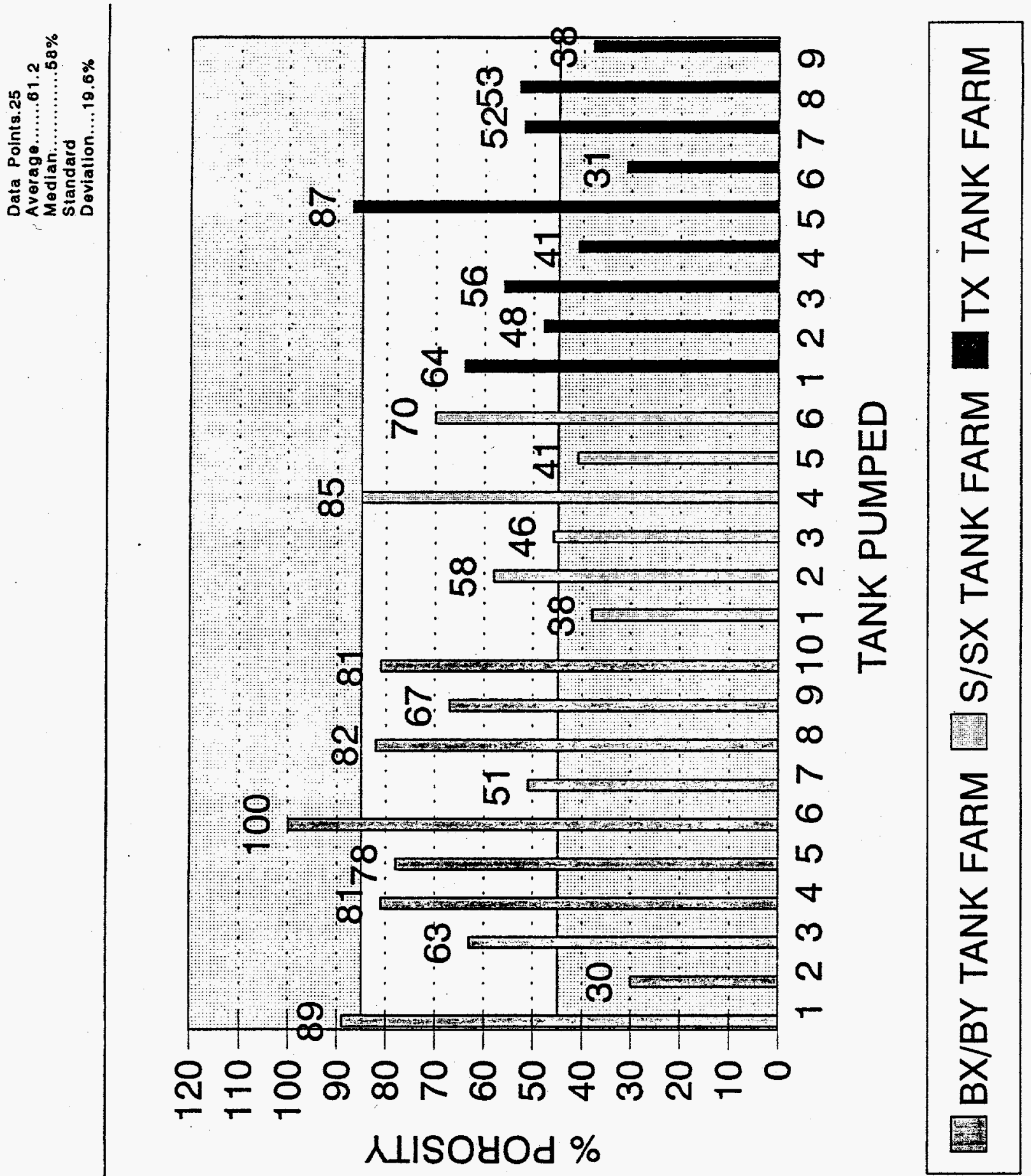
WHC-SD-W236A-ES-012

Revision 0

Figure 1-2. Porosity Values for Stabilized Single-Shell Sludge Tanks.
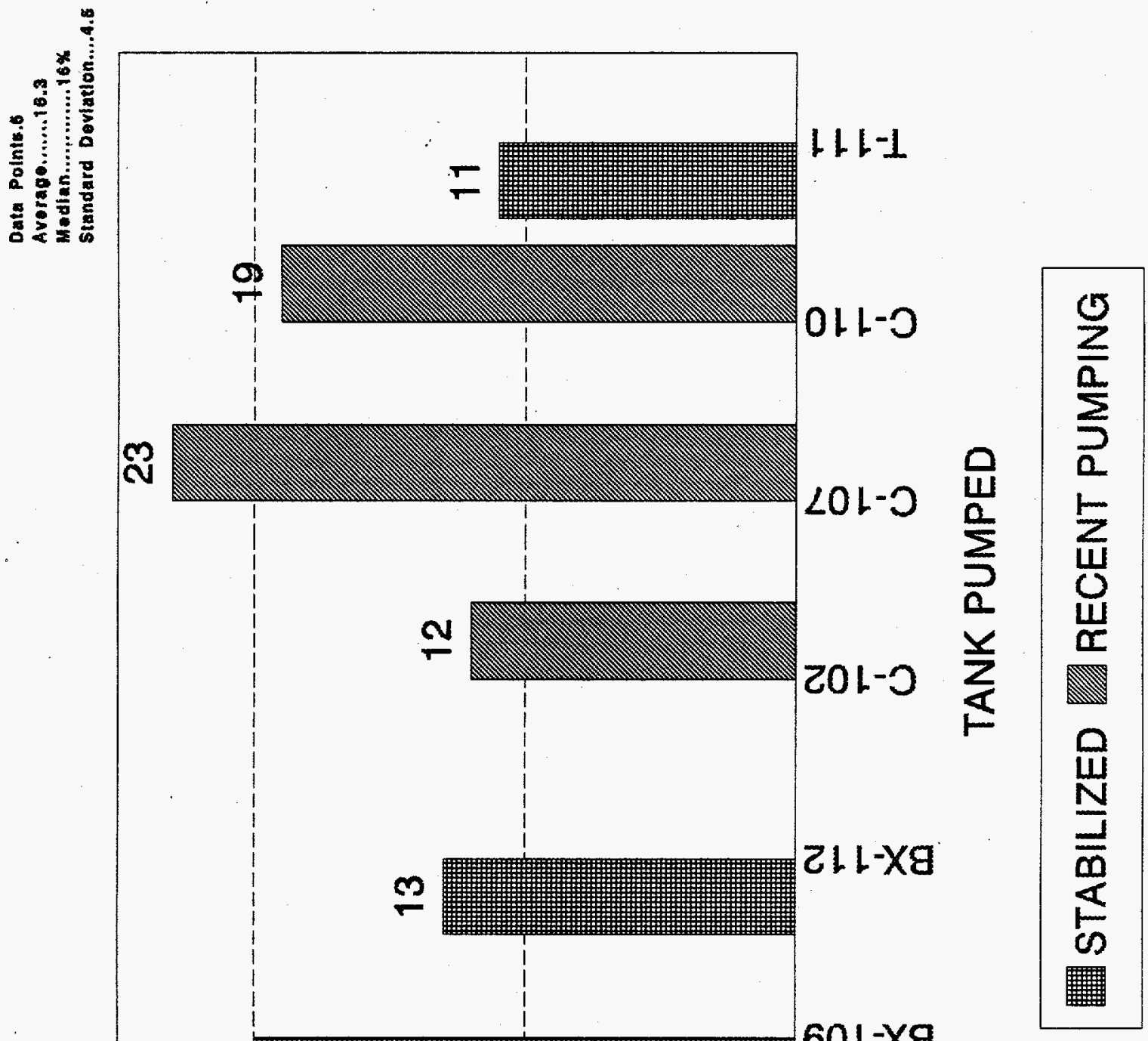

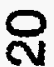

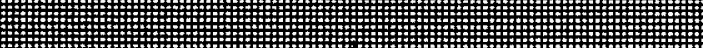

$601-\times 9$

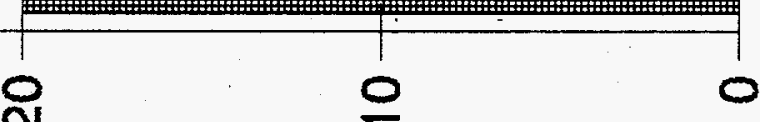

ᄉLISOYOd \% 


\subsection{PURPOSE AND NEED}

The Multi-Function Waste Tank Facility (MWTF) path forward tasks were initiated to provide information on the amount of additional safe storage capacity needed to meet the Tank Waste Remediation System's (TWRS) mission. Eight technical tasks were defined to provide a technical basis to determine the need for new tanks.

The purpose of this report is to respond to Task 3.3 in the internal memo, Technical Tasks - Action Plan to Support the MWTF Path Forward (Thompson 1994). This study determines (1) the quantity of 1iquid waste remaining in the SSTs that still requires stabilization, and (2) the quantity of flush water required to support the stabilization effort. As of March 27, 1995, 41 of the 149 SSTs on the Hanford Site still require stabilization. The majority of the SSTs remaining to be stabilized (27) are in the 200 West Area, and the other 14 are in the 200 East Area. Records for the SSTs that have been stabilized or partially pumped are examined in this report to gain insight into the pumping that remains. 
WHC-SD-W236A-ES-012

Revision 0

This page intentionally left blank. 


\subsection{DISCUSSION}

\subsection{BASIS TO DETERMINE LIQUIDS REMAINING IN SSTS}

One of the primary factors affecting the waste volume projections is how much 1 iquid waste must be pumped from the SSTs. Porosity of the SST sludge and salt cake is one of the main factors affecting these projections.

An accurate estimate of the liquid waste remaining in the SSTs wi11 require the following:

- An accurate solids classification for the SSTs. To provide consistent data between studies and recommendations on porosity, the same database needs to be used. This study identifies and updates the change in porosity values for the stabilized salt cake and sludge tanks using the data from the waste characterization reports.

- Examination of the pumping data from the seven unstabilized, jetpumped tanks in $S$ Farms. Previous studies could not agree on a porosity value because of the variation of the solids classification used. This study used the pumping records for liquids pumped and calculated the porosity based on waste volume from the waste characterization reports.

- Examination of the pumping data for the jet pump prototypes and the other stabilized tanks.

- Using actual pumping data to update porosity values as new data become available. This study used the pumping data from the four SSTs that were actively pumped during 1994 and compares it to the updated stabilized tank porosities. The resulting data provide the most complete records on actual pumping quantities.

Current waste volume projections use the porosity value to calculate the quantity of liquid that will drain from a salt cake and/or sludge. The term porosity is used to describe the volume fraction of drainable interstitial liquid in waste solids (Deweese 1988), excluding the capillary held region. The porosity values currently used tend to give low estimates of the actual pumpable liquid remaining (PLR) in the SSTs (see Appendix C). To predict the total pumpable volume of liquid remaining in a salt cake SST, three things have to be accounted for: (1) the supernatant above the salt cake, (2) interstitial liquid within the salt.cake, and (3) the 'pockets' and/or 'layers' of liquid distributed throughout the salt cake. Therefore, the tota? pumpable volume of liquid waste in an SST would be the sum of the volume of interstitial liquid calculated using the projected porosity and known quantities of supernatant within the tank. The porosity value used in this study to predict the amount of interstitial liquid in a salt cake SST will be referred to as the 'projected porosity value.' This term accounts for the interstitial liquid held in the pores of the salt cake, as well as for the pockets and/or layers of liquid within the salt cake minus known quantities of supernate. Once pumping begins in an SST, actual field-measured data should be used to recalculate the 'actual' porosity value for that individual tank. Figure 2-1 depicts the two methods of calculating the porosity term. 


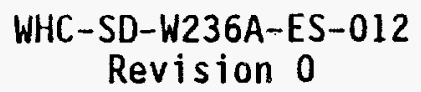

Figure 2-1. Salt Cake Porosity.
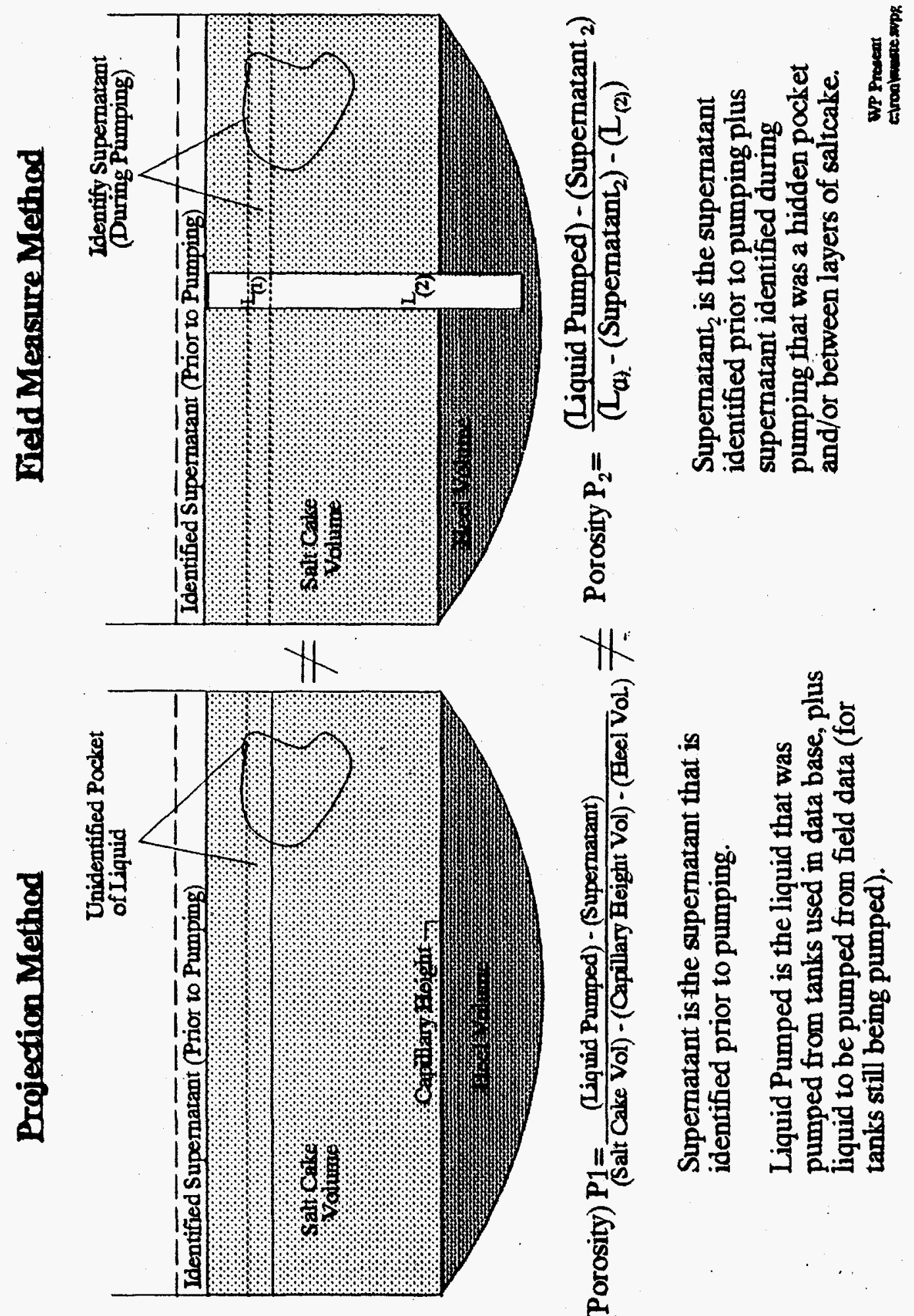

H

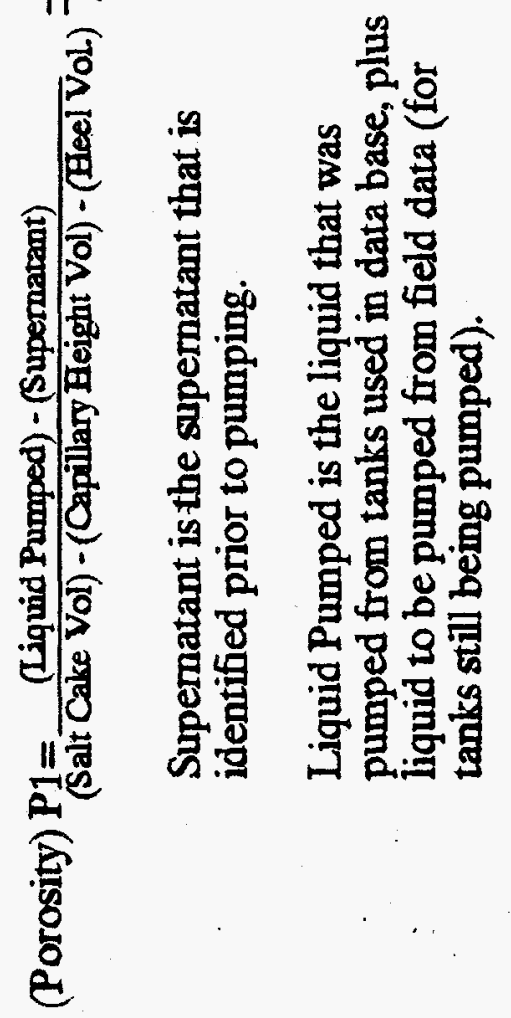


The prediction of PLR in a sludge tank is somewhat less complicated, because sludge tanks do not have hidden pockets or layers of liquid in them. The porosity value used to determine the PLR in a sludge tank uses a true sludge porosity. For salt cake tanks, the porosity value used is more of a projection porosity because it has to account for the hidden liquid pockets and layers of liquid in the salt cake.

The limited pumping experience on sludge tends to suggest that 'true' sludges are unpumpable. Pumping of tanks containing sludge has shown that some materials defined as sludge will have interstitial liquid flow properties similar to salt cake. However, large pockets or layers of hidden supernatant are not anticipated. The liquids projection for the sludge tanks is just over $5 \%$ of the total, which is not very significant.

\subsubsection{Assumptions Necessary for Data Interpretation}

The following assumptions were used to determine the salt cake and sludge porosities:

- Waste volume data from the waste characterization reports

- Once a tank becomes a bottoms receiver, any solids that accumulate are considered to be salt cake.

- For salt cake accumulation, all reported solids are considered to be salt cake.

- Solids were evenly distributed throughout the tank.

- Complete settling of the sludge occurred and the solids settled in a pseudo-pancake formation.

- The capacity of the tanks was never exceeded during transfers.

- Cascades, tank transfers, and crib line effluents were normally free of particulates; therefore, the majority of solids were confined to their initial receiver tanks and were not cribbed or transferred extensively between tanks.

- Salt well pumping data from the last 5 years is more reliable than pumping data from previous years (due to better procedural control, better records, better instrumentation, and improved conduct of operations).

- Data are taken from field measurements to calculate liquids removed from salt cake/sludge for SSTs currently being pumped (i.e., pumping began in 1994 and is continuing in 1995).

- Actual field-measured data were used to calculate porosity for 1 iquid waste removed.

- Existing methods and formulas were used to calculate pumpable liquid waste remaining in the SSTs. 
- The data concerning pumpable liquid waste remaining in the SSTs that have been, or are being, actively pumped, are taken from the Hanion report (Hanlon 1995) and have not been changed.

- The data obtained from the Tank Farm Operations are the most accurate.

\subsubsection{Determination of Salt Cake and Sludge Porosities}

In the waste characterization reports, the histories of the 149 SSTs were reviewed and tank layer models (TLM) were developed to confirm the classification of the solid wastes (Gaddis and Pickett 1994a, 1994b, and 1995). Using the solids volumes depicted in the TLMs, the salt cake porosities were recalculated for the 25 previously jet pump stabilized salt cake tanks and 6 stabilized sludge tanks. These calculations can be found in Appendix $A$. It should be noted that the SSTs from the TX Tank Farm were stabilized in the late 1970's to early 1980's. The TX Tank Farm consists of 18 SSTs. Of the 18 tanks, 16 are salt cake, and of these 16, 8 were assumed leakers. When the TX Tank Farm was stabilized, the major emphasis placed was on removing the liquid from the tanks to reduce environmental impact. The transfer records were not well maintained, and flush water volumes were not recorded regularly. Therefore, based on the lack of information on these tanks, and the fact that all of the TX tanks have been stabilized, the decision was made to use data from 9 of the 18 TX Tank Farm tanks for this study. See Appendix A for individual tank assessments.

The projected porosity value used to determine the pumpable liquid waste remaining in salt cake tanks for this study was calculated from data on the seven stabilized salt cake SSTs (BX-111, BY-101, BY-104, BY-107, BY-110 $B Y-111$, and BY-112); data on the five $S$ Tank Farm salt cake SSTS and one SX Tank Farm salt cake SST that have been pumped (SX-104, S-105 [stabilized], S-106, S-108, S-110 and S-112); data on the recent pumping of three tanks (BY-102, BY-103, and BY-109); and data on the nine stabilized TX Tank Farm salt cake SSTs (TX-102, TX-105, TX-106, TX-110, TX-111, TX-112, TX-113, TX-114, and TX-118). The porosity value used to determine the pumpable liquid waste remaining in sludge tanks for this study was calculated from data on the sludge tanks (three stabilized tanks, BX-109, BX-112, and T-111) and three tanks that have been previously pumped or are currentiy being pumped $(C-102$, $\mathrm{C}-107$; and $(-110)$. These tanks have been chosen as the primary database for this study because they are believed to represent the most current and accurate tank stabilization data available.

After the porosity values for each individual tank were calculated, the average was determined to be approximately $61 \%$ for salt cake tanks and $16 \%$ for sludge tanks (see Appendix B, Tables B-1 and B-2).

A comparison study was performed to verify the applicability of using the average porosity values determined. The study used the 25 stabilized salt cake tanks database and compared how $35 \%, 45 \%$, and $61 \%$ salt cake porosity values predict the PLR in the SSTs with the actual volume of pumpable liquid initially in the stabilized SSTs. The initial volume of pumpable liquid in the SSTs was determined by adding the volume of liquid waste (both supernatant and interstitial) removed by pumping and the pumpable liquid estimated to be 
remaining in the tanks after pumping was completed. Also, the solids volumes used were the estimates used before pumping started. The results of this comparison show that $5.4 \mathrm{Mgal}$ of pumpable liquid waste were initially contained in the 25 SSTs used for this study. The $35 \%$ salt cake porosity predicted that the volume of PLR in the SSTs was $3.5 \mathrm{Mgal}$, an underestimate of $1.9 \mathrm{Mgal}$. The $45 \%$ salt cake porosity predicted that the volume of PLR in the SSTs was $4.4 \mathrm{Mgal}$; this underestimates the actual volume of PLR by $1 \mathrm{Mgal}$. When using the $61 \%$ projection salt cake porosity, a prediction was made at $6.0 \mathrm{Mgal}$; this overshoots the actual volume by $605 \mathrm{kgal}$ (see Appendix $\mathrm{C}$, Table $(-1)$.

A similar comparison was made using the sludge tanks. The results of this comparison show that the $12.5 \%$ sludge porosity underestimates the actual volume of PLR by $22 \mathrm{kgal}$. The $16 \%$ sludge porosity overestimates the actual volume of PLR by $13 \mathrm{kgal}$ (see Appendix C, Table $\mathrm{C}-2$ ).

\subsubsection{PLR}

Based on the average projected porosity value of $61 \%$ for salt cake tanks and an average sludge porosity value of $16 \%$, the baseline case indicates that the PLR in the SSTs is $6.0 \mathrm{Mgal}$ (see Figure 2-2).

Compared to the $45 \%$ salt cake porosity used by the Hanlon report, an additional $1.0 \mathrm{Mgal}$ of 1 iquid will require storage capacity (see Appendix D, Table D-1).

Compared to the $35 \%$ salt cake porosity used by the operational waste volume projection, an additional $1.8 \mathrm{Mgal}$ of 1 iquid will require storage capacity (see Appendix D, Table D-1).

The $61 \%$ projected salt cake and $16 \%$ sludge porosities provide a good overall estimate of the liquid waste volume remaining in the SSTs. However, these porosity percentages are not exact and will not accurately estimate the volume of pumpable liquid waste remaining in each SST requiring stabilization. As the data show, the porosity value of the salt cake ranges from $30 \%$ to $100 \%$, and the sludge porosity varies from $11 \%$ to $23 \%$. Currently, there is no way to accurately predict the volume of liquid waste in each individual tank before pumping takes place. Inaccuracies in the solids measurements and the inability to accurately estimate supernatant volumes contribute to the spread of data and the high porosities exhibited by the database. It is emphasized that when the actual amounts of 1 iquid recorded as pumped from the tanks are plugged into the equation, they give the salt cake structure a porosity which includes the pools and pockets/layers of liquid. This has the affect of increasing the salt cake porosity, in some cases over $100 \%$, which is not physically possible. The error results because one key assumption is erroneous. The salt cake is not a uniformly distributed structure. It contains significant quantities of pools and layers of liquid (supernatant). 


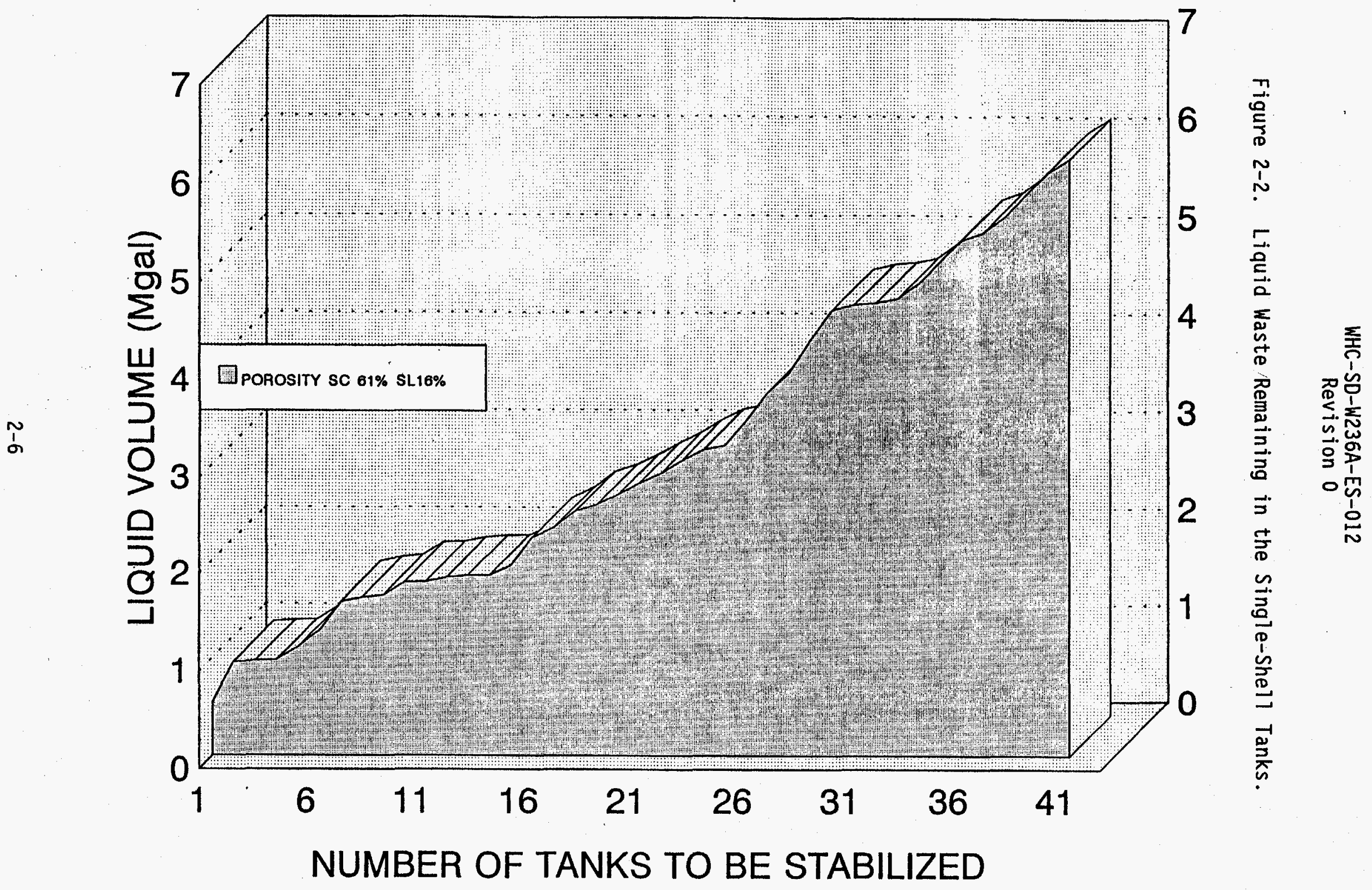




\subsection{BASIS TO DETERMINE FLUSH WATER REQUIREMENTS}

Flush water requirements were determined by going through the operating procedures and by following the TWRS Daily Operating Reports to estimate the average number of pump shutdowns that occur during the stabilization of an SST.

From these data, the set of assumptions (see Section 2.2.1) was developed to estimate flush water that would be added to the DSTs. The flush water estimate includes the flushing for the salt well pumping equipment, transfer to the DCRT, and transfer to the DST for storage. The estimate excludes flush water that would be required to transfer between the 200 West and 200 East Area Tank Farms.

\subsubsection{Flush Water Assumptions}

The following assumptions were used to determine the amount of flush water required.

- Liquid waste is salt well pumped from an SST to a DCRT (20 kgal capacity).

- The salt well pumping system is flushed when the DCRT is filled.

- The salt well pumping system is flushed after downtime periods longer than 4 hours.

- The salt well system will experience two downtime periods longer than 4 hours for every $20 \mathrm{kgal}$ of 1 iquid removed from the SSTs.

- The salt well and DCRT systems will require $5.2 \mathrm{kgal}$ of flush water for every $20 \mathrm{kgal}$ of liquid removed from the SSTs.

\subsection{SEGREGATION OF COMPLEX WASTE}

Historically, complexed waste and transuranic (TRU) waste have been segregated for tank storage to minimize the amount of waste that requires more expensive disposal and to comply with U.S. Department of Energy (DOE) Orders. The DOE Order 5820.2a, Radioactive Waste Management (DOE 1988), states in Section I.3.b.(2)(e), "To the extent practical, waste shall be segregated by type (sludge, salt, high activity, and low activity) to make accessibility for future processing easier," and in Section II.3.e.(1), "Transuranic waste șall be segregated or otherwise clearly identified to avoid combining of transuranic waste streams with high-level waste or low-level waste." The Hanford Site has implemented this practice by segregating waste that was considered complex ( $>10 \mathrm{~g} / \mathrm{L}$ total organic carbon) from TRU waste sludge (Reynolds 1995).

Processing problems in the evaporator are another reason for segregating complex waste from other waste types. The organic complexants interfere with the crystallization process resulting in extremely thick, viscous slurries. When complexed waste and noncomplexed waste are mixed, the noncomplexed waste 
cannot be evaporated to as low a volume as when it is alone. Therefore, there is a potential for a net loss of space in the tank farms by mixing complexed and noncomplexed waste. Complexed waste also adds to the complexity of pretreatment for final disposal. The pretreatment of waste before vitrification calls for a step that destroys the organic compounds and releases the TRU (Orme 1994). If complexed waste is not segregated but blended with other waste, there is a potential that more waste will have to go through the organic destruction process. This will add complexity and cost to the final disposal of the waste (Reynolds 1995).

An estimated $1.8 \mathrm{Mgal}$ of potentially complexed waste remain to be pumped from the 200 East and 200 West Area SSTs. Table E-1 in Appendix E shows the breakdown of complexed versus noncomplexed SSTs in the Hanford Site 200 Areas. The division of complexed versus noncomplexed SSTs in the 200 West Area is from WHC-SD-W236A-015, Waste Segregation Analysis for Salt Well Pumping in the 200 West Area (Reynolds 1995). 


\subsection{RESULTS AND CONCLUSIONS}

\subsection{RESULTS}

The waste characterization reports (Gaddis and Pickett 1994a, 1994b, and 1995) combine all historical data available for Hanford Site waste and provide a consistent base for all future porosity and liquid waste in SST studies. The comparison of the present $45 \%$ salt cake porosity value, adjusted for salt cake volumes using the waste characterization report values, does not accurately project the value of the PLR in the unstabilized SSTs. A projected porosity value must be used to account for the hidden pockets of liquid in the salt cakes.

Data obtained for pumping operations during the 1980's are based on best available data; however, data sources are extracted from early reports and cannot be verified. Data for the liquid waste pumped from the TX Tank Farm tanks consisted mainly of calculated amounts using engineering best judgement. Data from 7 of the 16 stabilized TX Tank Farm salt cake tanks were not used for the 31-tank study sample because the data were inaccurate.

The 31-tank study sample used to calculate the projected porosity value for salt cake/sludge tanks consisted of the salt cake/sludge tanks with the best retrievable data. The current pumping activity (1994/95) is the most reliable.

Flush water (1.6 Mgal) needs to be considered as part of the storage requirements, and will need interim storage space in the DST until it can be evaporated.

\subsection{CONCLUSIONS}

The projected PLR in the SSTs is $6.0 \mathrm{Mgal}$, based on the average projected salt cake porosity value of $61 \%$ and sludge porosity value of $16 \%$ derived from this study. A projected salt cake porosity value of $61 \%$ provides a good estimate for the overall volume of pumpable liquid waste remaining in the SSTs still requiring stabilization. However, the database had varying salt cake porosities that ranged from $30 \%$ to $100 \%$, with a standard deviation of $19.6 \%$. This implies that the confidence of any one tank having a salt cake porosity of $61 \%$ is low. However, when compared to a salt cake porosity of $45 \%, 61 \%$ projected salt cake porosity provided a better estimate of PLR in the 25-salt cake tank study sample used. With $5,484 \mathrm{kgal}$ of pumpable liquid initially contained in the 25-salt cake study sample, a $45 \%$ salt cake porosity provides an estimate of $4,433 \mathrm{kgal}$, an underestimate of $941 \mathrm{kgal}$. A $61 \%$ projected salt cake porosity estimates the PLR to be $5979 \mathrm{kgal}$, an overestimate of just $605 \mathrm{kgal}$. Therefore, it is the recommendation of this report to use a $61 \%$ projected salt cake porosity to predict the volumes of pumpable liquid waste remaining in the SSTs containing salt cake solids still requiring stabilization. 
WHC-SD-W236A-ES-012

Revision 0

This page intentionally left blank. 


\section{WHC-SD-W236A-ES-012 \\ Revision 0}

\subsection{RECOMMENDATIONS}

The following recommendations are made as a result of the study.

1. Use the Tank Characterization Database (TCD) as the official source for waste tank characterization data.

2. Update the TCD to show the liquids remaining within the SSTs, using the revised projected porosity values as determined by this report.

3. Reliable data on total liquid pumped from each SST should be recorded and the projected porosity value recalculated to give better determination for future 1 iquid projections as tanks are pumped. The data should then be used to make annual revisions to the TCD. 
WHC-SD-W236A-ES-012

Revision 0

This page intentionally left blank. 


\subsection{REFERENCES}

Alumka1, W. T., 1995, Multi-Function Waste Tank Facility - Decision Paper, (Letter 9550111 to T. R. Sheridan, U.S. Department of EnergyHeadquarters), Westinghouse Hanford Company, Richland, Washington.

Anderson, J. D., and 0. C. Mudd, 1990, A History of the 200 Area Tank Farms, WHC-MR-0132, Westinghouse Hanford Company, Richland, Washington.

DeWeese, G. C., 1988, Observed Porosities of Single-Shell Tank Waste Salt Cakes and Sludge, WHC-SD-WM-TI-328, Rev. 0, Westinghouse Hanford Company, Richl and, Washington.

DOE, 1988, Radioactive Waste Management, DOE Order 5820.2A, Westinghouse Hanford Company, Richland, Washington.

Forney, C. E., 1989, Single-Shell Tank Waste Pumping Strategy, WHC-SD-WM-TI-274, Rev. 0, Westinghouse Hanford Company, Richland, Washington.

Gaddis, L. A., and W. W. Pickett, 1994a, Historical Tank Content Estimate for the Southwest Quadrant of the Hanford 200 West Areas, WHC-SD-WM-ER-352, Rev. 0, Westinghouse Hanford Company, Richland, Washington.

Gaddis, L. A., and W. W. Pickett, 1994b, Historical Tank Content Estimate for the Northeast Quadrant of the Hanford 200 East Areas, WHC-SD-WM-ER-349, Rev. 0, Westinghouse Hanford Company, Richland, Washington.

Gaddis, L. A., and W. W. Pickett, 1995, Historical Tank Content Estimate for the Northwest Quadrant of the Hanford 200 West Area, WHC-SD-WM-ER-351, Rev. 0 , Westinghouse Hanford Company, Richland, Washington.

Handy, L. L., 1975, Flow Properties of Salt Cake and Interstitial Liquid Removal/Immobilization Development Program, ARH-C-6, Westinghouse Hanford Company, Richland, Washington.

Hanlon, B. M., 1995, Waste Tank Summary Report for Month Ending December 31, 1994, WHC-EP-0182-81, Issued Monthly, Westinghouse Hanford Company, Richland, Washington.

Klem, M. J., 1986, Salt Well Pumping Strategy, SD-WM-TI-274, Westinghouse Hanford Company, Richland,. Washington.

Metz, W. P., 1976, A Topical Report on Interstitial Liquid Removal from Hanford Salt Cakes, ARH-CD-545, Westinghouse Hanford Company, Richland, Washington.

Orme, R. M., 1994, TWRS Process Flowsheet, WHC-SD-TI-613, Rev. 0, Westinghouse Hanford Company, Richland, Washington.

Reynolds, D. A., 1995, Waste Segregation Analysis for Salt Well Pumping in the 200 West Area, WHC-SD-W236A-015, Rev. 0, Westinghouse Hanford Company, Richl and, Washington. 
Sederburg, J. P., 1995, Waste Volume Reduction Factors for Potential 242-A Evaporator Feed, WHC-SD-WM-TI-690, Rev. 0, Westinghouse Hanford Company, Richland, Washington.

Strachan, D. M., 1975, Permeability, Capillarity and Pore Volume of Synthetic Hanford Salt Cake, ARH-ST-129, Westinghouse Hanford Company, Richland, Washington.

Strode, J. N., 1994, Operational Waste Volume Projection, WHC-SD-WM-ER-029, Rev. 20, Westinghouse Hanford Company, Richland, Washington.

Thompson, J. D., 1994, Technical Tasks - Action Plan To Support The MWTF Path Forward (Letter to L. F. Ermold, DRAFT), Westinghouse Hanford Company, Richland, Washington. 


\subsection{BIBLIOGRAPHY}

Awadalla, N. G., 1994, Position Paper, Need for Additional Waste Storage Capacity and Recommended Path Forward for Project W-236A, Mu7ti-Function Waste Tank Facility, WHC-SD-W236A-ER-011, Rev. 0, Westinghouse Hanford Company, Richland, Washington.

Joncus, S. J., 1983, Guideline For Declaring Single-Shell Tanks Interim Stabilized Following Jet Pumping,-WHC-SD-RE-TI-099, Rev. 0, Westinghouse Hanford Company, Richland, Washington.

Jungfleisch, F. M., 1984, Preliminary Estimation of the Waste Inventories in Hanford Tanks Through 1980, SD-WM-TI-057, Rev. 0, Westinghouse Hanford Company, Richland, Washington.

Kirk, J. J., 1980, Permeability, Porosity, and Capillarity of Hanford Waste Material and Its Limits of Pumpability, RHO-CD-925, Rev. 1, Westinghouse Hanford Company, Richland, Washington.

Klem, M. J., 1988, Technology Program Plan for Interim Stabilization of Single-She17 Tanks Between FY87 and FY96, SD-WM-TPP-031, Rev. 1, Westinghouse Hanford Company, Richland, Washington.

K1em, M.J., 1990, Single-Shell Tank Interim Stabilization Criteria Review, WHC-SD-WM-DIC-005, Rev. 0, Westinghouse Hanford Company, Richland, Washington.

Larrick, A. P., 1994, Project W-236A Multi-Function Waste Tank Facility Waste Feed Projections, SD-W236A-TS-001, Rev. 0, Westinghouse Hanford Company, Richl and, Washington.

Metz, W. P., and Ogren, W. E., 1976, Criteria - Waste Tank Isolation and Stabilization, ARH-CD-784, Westinghouse Hanford Company, Richland, Washington.

Molberg, T. P., 1991, Jet Pump Duration To Stabilize Remaining Single-Shell Tanks (Letter 77130-91-0112 to V. C. Boyles), Westinghouse Hanford Company, Richland, Washington.

Swaney, S. L., 1994, Single Shell Tank Stabilization Record, WHC-SD-RE-TI-178, Rev. 4, Westinghouse Hanford Company, Richland, Washington.

Tank Farm Process Engineering, 82/01/00 thru 86/12/00, Waste Status Summary, RHO-RE-SR-14, Issued Monthly, Westinghouse Hanford Company, Richland, Washington.

Weiss, R. L., 1986, TY Tank Farm Waste Characterization Data, RHO-WM-TI-1 P, Westinghouse Hanford Company, Richland, Washington. 
WHC-SD-W236A-ES-012

Revision 0

This page intentionally left blank. 
WHC-SD-W236A-ES-012

Revision 0

\subsection{GLOSSARY}

\section{ABBREVIATIONS AND ACRONYMS}

$\begin{array}{ll}\text { DCRT } & \text { double-contained receiver tank } \\ \text { DOE } & \text { U.S. Department of Energy } \\ \text { DST } & \text { double-shell tank } \\ \text { MWTF } & \text { Multi-Function Waste Tank Facility } \\ \text { PLR } & \text { pumpable liquid remaining } \\ \text { SST } & \text { single-shell tank } \\ \text { TCD } & \text { Tank Characterization Data } \\ \text { TLM } & \text { tank layer model } \\ \text { TRU } & \text { transuranic } \\ \text { TWRS } & \text { Tank Waste Remediation System }\end{array}$

\section{DEFINITIONS OF TERMS}

Projection Porosity. A projection factor to determine liquids in waste tanks based on salt cake content. 
WHC-SD-W236A-ES-012

Revision 0

This page intentionally left blank. 
WHC-SD-W236A-ES-012

Revision 0

APPENDIX A

POROSITY CALCULATIONS

A-1 
WHC-SD-W236A-ES-012
Revision 0

This page intentionally left blank. 
Total BX-111 Tank Inventory

1980

- Sludge

- Salt cake

- Supernatant

Total waste
$32 \mathrm{kgal}$

$179 \mathrm{kgal}$

$\frac{22 \mathrm{kgal}}{233 \mathrm{kgal}}$
1994

$$
\begin{array}{r}
32 \mathrm{kgal} \\
179 \mathrm{kgal} \\
19 \mathrm{kgal} \\
\hline 230 \mathrm{kgal}
\end{array}
$$

Total liquid pumped (1995)

Total projected pumpable liquid remaining (PLR) (field data)

Total supernate removed

Total volume leaked

$119.1 \mathrm{kgal}$

$0.0 \mathrm{kgal}$

$33.0 \mathrm{kgal}$

$8.0 \mathrm{kgal}$

Based on data for 1980 , salt cake volume, and total liquid pumped plus PLR (field data)

Porosity $_{\text {sc }}\left(P_{\text {sc }}\right)=\frac{\text { Liquid removed }+P L R-\text { supernatant removed }}{\text { Volume of salt cake }-82.5^{*}} \times 100$

$P_{s c}=\frac{119.1+0-33}{179-82.5} \times 100$

$P_{\text {sc }}=89 \%$

The pumping includes quantities of supernatant as hidden pockets/layer. Salt cakes tend to form irregular surfaces, and occasionally floating crusts and/or pockets form above or around a layer of supernatant.

As of March 1995, salt well pumping for BX-111 has been completed and was declared interim stabilized.

*Constant--Compensates for capillary and unpumpable height within tank. 
Revision 0

Porosity BY -101

Total BY-101 Tank Inventory
(STABILIZED 1984)

1977

1994

- Sludge

- Salt cake

- Supernatant

Total waste

$\begin{array}{r}37 \mathrm{kgal} \\ 402 \mathrm{kgal} \\ 0 \mathrm{kgal} \\ \hline 439 \mathrm{kgal}\end{array}$

$37 \mathrm{kgal}$

$350 \mathrm{kgal}$

$\frac{0 \mathrm{kgal}}{387 \mathrm{kgal}}$

Total liquid pumped (1977)

Total liquid pumped (1984)

Total projected PLR (field data)

Total supernate removed

$61.6 \mathrm{kga} 1$

$35.8 \mathrm{kga} 7$

$0.0 \mathrm{kgal}$

$0.0 \mathrm{kgat}$

Based on data for 1977, salt cake volume, and total liquid pumped (field data)

Porosity $_{\text {sc }}\left(P_{\text {sc }}\right)=\frac{\text { Liquid removed }+P L R-\text { supernatant removed }}{\text { Volume of salt cake }-82.5^{*}} 100$

Porosity $_{\text {sc }}\left(P_{\text {sc }}\right)=\frac{97.4+0-0}{402-82.5} \times 100$

$P_{\text {sc }}=30 \%$

The pumping includes quantities of supernatant as hidden pockets/layer. A noticeable change in the solids volume $(-52 \mathrm{kgal})$ occurred after removal of the 1iquid. Salt cakes tend to form irregular surfaces, and occasionally floating crusts and/or pockets form above or around a layer of supernatant.

*Constant--Compensates for capillary and unpumpable height within tank. 
Revision 0

Porosity BY -102

Total BY-102 Tank Inventory
(RECENT PUMPING)

1978

1994

- Sludge

- Salt cake

- Supernatant

Total waste

$\begin{array}{r}29 \mathrm{kgal} \\ 388 \mathrm{kgal} \\ 0 \mathrm{kgal} \\ \hline 417 \mathrm{kgal}\end{array}$

$29 \mathrm{kgal}$

$312 \mathrm{kgal}$

$\frac{0 \mathrm{kgal}}{341 \mathrm{kgal}}$

Total liquid pumped (1978 - 1979)

Total liquid pumped (1991 - 1994)

$34.6 \mathrm{kgal}$

$151.4 \mathrm{kgal}$

$6.7 \mathrm{kga} 7$

$0.0 \mathrm{kgal}$

Based on data for 1978, salt cake volume, and total liquid pumped plus PLR (field data).

Porosity $_{\text {sc }}\left(P_{\text {sc }}\right)=\frac{\text { Liquid removed }+ \text { PLR }- \text { supernatant removed }}{\text { Volume of salt cake }-82.5^{*}} \times 100$

$P_{\text {sc }}=\frac{186+6.7-0}{388-82.5} \times 100$

$P_{s c}=63 \%$

The pumping included quantities of supernatant as hidden pockets/layer.

A noticeable change in the solids volume ( $-76 \mathrm{kgal})$ occurred after removal of the liquid. Salt cakes tend to form irregular surfaces, and occasionally floating crusts and/or pockets form above or around a layer of supernatant.

*Constant--Compensates for capillary and unpumpable height within tank. 
Revision 0

Porosity BY -103

(RECENT PUMPING)

Assumed Leaker

Total tank inventory

1978

1994

- Sludge

- Salt cake

- Supernatant

Total waste

$9 \mathrm{kgal}$

$452 \mathrm{kgal}$

$\frac{0 \mathrm{kgal}}{461 \mathrm{kgal}}$

$9 \mathrm{kgal}$

$391 \mathrm{kgal}$

$\frac{0 \mathrm{kgal}}{400 \mathrm{kgal}}$

Total liquid pumped (1979)

Total liquid pumped (1987 - 1994)

Total projected PLR (field data)

Total supernate removed

Total volume leaked (greater than)

$84.4 \mathrm{kgal}$

$78.5 \mathrm{kgal}$

$137.0 \mathrm{kgal}$

$0.0 \mathrm{kgal}$

$5.0 \mathrm{kgal}$

Based on data for 1978, salt cake volume, and total Tiquid pumped plus PLR (field data)

Porosity $_{\text {sc }}\left(P_{\text {sc }}\right)=\frac{\text { Liquid removed }+ \text { PLR }- \text { supernatant removed }}{\text { Volume of salt cake }-82.5^{*}} 100$

$P_{s c}=\frac{162.9+137-0}{452-82.5} \times 100$

$P_{\text {sc }}=81 \%$

The pumping included quantities of supernatant as hidden pockets/layer.

A noticeable change in the solids volume $(-61 \mathrm{kgal})$ occurred after removal of the 1iquid. Salt cakes tend to form irregular surfaces, and occasionally floating crusts and/or pockets form above or around a layer of supernatant.

*Constant--Compensates for capillary and unpumpable height within tank. 
Total BY-104 Tank Inventory

- Sludge

- Salt cake

- Supernatant

Total waste
$150 \mathrm{kgal}$

$473 \mathrm{kgal}$

$\frac{11 \mathrm{kgal}}{634 \mathrm{kgal}}$
$150 \mathrm{kga} 7$

$256 \mathrm{kga} 7$

$\frac{0 \mathrm{kgal}}{406 \mathrm{kgal}}$

Total liquid pumped (1983 - 1984)

Total projected PLR (field data)

Total supernate removed (field data)

$329.5 \mathrm{kgal}$

$0.0 \mathrm{kga}]$

$11.0 \quad \mathrm{kgal}$

Based on data for 1980 , salt cake volume, and total liquid pumped (field data)

Porosity $\left(P_{s c}\right)=$ Lqd rmvd $+P L R-\left(S l\right.$ udge vol $\left.-66^{*}\right) \times P_{s l^{-}}$supnate rmvd Volume of salt cake $-82.5^{\star \star}$

$P_{s c}=\frac{329.5+0-24.4}{473-82.5} \times 100$

$P_{s c}=78 \%$

The pumping included quantities of supernatant as hidden pockets/layer. A noticeable change in the solids volume $(-217 \mathrm{kgal})$ occurred after removal of the liquid. Salt cakes tend to form irregular surfaces, and occasionally floating crusts and/or pockets form above or around a layer of supernatant.

* Constant--Compensates for capillary height for sludge within tank.

** Constant--Compensates for capillary and unpumpable height within tank. 
Total BY-107 Tank Inventory

- Sludge

- Salt cake

- Supernatant

Total waste
1975

$$
\begin{array}{r}
117 \mathrm{kgal} \\
250 \mathrm{kgal} \\
0 \mathrm{kgal} \\
\hline 367 \mathrm{kgal}
\end{array}
$$

1994

$$
\begin{array}{r}
117 \mathrm{kgal} \\
149 \mathrm{kgal} \\
0 \mathrm{kgal} \\
\hline 266 \mathrm{kgal}
\end{array}
$$

Total liquid pumped (1975)

Total liquid pumped $(1976$ - 1979)

Total PLR (field data)

Total supernate removed

Total volume leaked
$153.1 \mathrm{kgal}$

$56.4 \mathrm{kga} 7$

$0.0 \mathrm{kgal}$

$0.0 \mathrm{kgal}$

$15.1 \mathrm{kgal}$

The following formula has been used in the past (and is currently being used) to predict the amount of liquid that can be pumped from a salt cake structure. However, when the liquid was actually pumped out, the tank BY-107 and that ACTUAL amount of liquid pumped was plugged into the equation. That gave the salt cake structure a porosity of $120 \%$, which is not physically possible. The error results because one key assumption is erroneous. The saltcake is not a uniformly distributed structure. It contains significant quantities of pools and layers of liquid (supernatant). In the case of tank BY-107, a volume of $101 \mathrm{kgal}$ was attributed to salt cake but it really was liquid.

Based on data for 1975, salt cake volume, and total liquid pumped (field data) Porosity $\left(P_{\text {sc }}\right)=$ Lqd rmvd + PLR - (Sludge vol $\left.-66^{*}\right) \times P_{\text {sl }}$ - supnate rmvd Volume of salt cake $-82.5^{\star \star}$

$$
\begin{aligned}
& P_{\text {sc }}=\frac{209.5+0-8.16}{250-82.5} \times 100 \\
& P_{s c}=120 \%
\end{aligned}
$$

${ }^{*}$ Constant--Compensates for capillary height for sludge within tank.

${ }^{\star *}$ Constant--Compensates for capillary and unpumpable height within tank. 
Porosity BY-109

Total BY-109 Tank Inventory
1994

\begin{tabular}{rl}
36 & $\mathrm{kgal}$ \\
397 & $\mathrm{kgal}$ \\
0 & $\mathrm{kgal}$ \\
\hline 433 & $\mathrm{kgal}$
\end{tabular}

$36 \mathrm{kgal}$

$387 \mathrm{kgal}$

$\frac{0 \mathrm{kgal}}{423 \mathrm{kgal}}$

Total liquid pumped (1991 - 1994)

Total projected PLR (field data)

Total supernate removed

(RECENT PUMPING)

- Sludge

- Supernatant

Total waste

Based on data for 1984, salt cake volume, and total liquid pumped plus PLR (field data)

Porosity $_{\text {sc }}\left(P_{\text {sc }}\right)=\frac{\text { Liquid removed }+P L R-\text { supernatant removed }}{\text { Volume of salt cake }-82.5^{*}} 100$

$P_{s c}=\frac{117.4+43.2-0}{397-82.5} \times 100$

$P_{s c}=51 \%$

The pumping included quantities of supernatant as hidden pockets/layer.

A noticeable change in the solids volume $(-10 \mathrm{kgal})$ occurred after removal of the liquid. Salt cakes tend to form irregular surfaces, and occasionally floating crusts and/or pockets form above or around a layer of supernatant.

"Constant--Compensates for capillary and unpumpable height within tank. 
Total BY-110 Tank Inventory

1980

- Sludge

- Salt cake

- Supernatant Total waste

$\begin{array}{r}190 \mathrm{kgal} \\ 315 \mathrm{kgal} \\ 3 \mathrm{kgal} \\ \hline 508 \mathrm{kgal}\end{array}$

1994

$190 \mathrm{kgal}$

$208 \mathrm{kgal}$

$\frac{0 \mathrm{kgal}}{398 \mathrm{kgal}}$

Total 1iquid pumped (1983 - 1984)

Total projected PLR (field data)

$213.3 \mathrm{kgal}$

$0.0 \mathrm{kga} 7$

Total supernate removed

Based on data for 1980 , salt cake volume, and total liquid pumped (field data)

Porosity $\left(P_{\text {sc }}\right)=$ Lqd rmvd + PLR $-\left(S 1\right.$ udge vol $\left.-66^{*}\right) \times P_{s l^{-}}$supnate rmvd Volume of salt cake $-82.5^{\star \star}$

$P_{\text {sc }}=\frac{213.3+0-22.8}{315-82.5} \times 100$

$P_{\text {sc }}=82 \%$

The pumping included quantities of supernatant as hidden pockets/layer.

A noticeable change in the solids volume (-107 kgal) occurred after removal of the liquid. Salt cakes tend to form irregular surfaces, and occasionally floating crusts and/or pockets form above or around a layer of supernatant.

${ }^{*}$ Constant--Compensates for capillary height for sludge within tank.

** Constant--Compensates for capillary and unpumpable height within tank. 
Total BY-111 Tank Inventory

- Sludge

- Salt cake

- Supernatant

Total waste
$26 \mathrm{kgal}$

$589 \mathrm{kgal}$

$\frac{0 \mathrm{kgal}}{615 \mathrm{kgal}}$

$$
\begin{array}{rr}
26 & \mathrm{kgal} \\
433 & \mathrm{kgal} \\
0 & \mathrm{kgal} \\
\hline 459 & \mathrm{kgal}
\end{array}
$$

Total 1iquid pumped (1978)

Total liquid pumped $(1983$ - 1984)

Total projected PLR (field data)

Total supernate removed (field data)
$28.1 \mathrm{kgal}$

$313.3 \mathrm{kgal}$

$0.0 \mathrm{kgal}$

$0.0 \mathrm{kgal}$

Based on data for 1977, salt cake volume, and total liquid pumped (field data)

Porosity $_{\text {sc }}\left(P_{\text {sc }}\right)=\frac{\text { Liquid removed }+P L R-\text { supernatant removed }}{\text { Volume of salt cake }-82.5^{*}} 100$

$P_{s c}=\frac{341.4+0-0}{589-82.5} \times 100$

$P_{\text {sc }}=67 \%$

The pumping included quantities of supernatant as hidden pockets/layer.

A noticeable solids volume change $(-156 \mathrm{kgal})$ occurred after removal of the 7iquid. Salt cakes tend to form irregular surfaces, and occasionally floating crusts and/or pockets form above or around a layer of supernatant.

*Constant--Compensates for capillary and unpumpable height within tank. 
Total BY-112 Tank Inventory

1976

- Sludge

- Salt cake

- Supernatant

Total waste

$$
\begin{array}{rl}
26 & \mathrm{kgal} \\
284 & \mathrm{kgal} \\
0 & \mathrm{kgal} \\
\hline 310 & \mathrm{kgal}
\end{array}
$$

1994

$$
\begin{array}{r}
26 \mathrm{kgal} \\
274 \mathrm{kgal} \\
0 \mathrm{kgal} \\
\hline 290 \mathrm{kgal}
\end{array}
$$

Total liquid pumped (1976)

Total 1iquid pumped $(1983$ - 1984))

Total projected PLR (field data)

Total supernate removed (field data)
$46.9 \mathrm{kgal}$

$116.4 \mathrm{kgal}$

$0.0 \mathrm{kgal}$

$0.0 \mathrm{kgal}$

Based on data for 1976, salt cake volume, and total liquid pumped (field data)

Porosity $_{\text {sc }}\left(P_{\text {sc }}\right)=\frac{\text { Liquid removed }+P L R-\text { supernatant removed }}{\text { Volume of salt cake }-82.5^{*}} \times 100$

$P_{s c}=\frac{163.3+0-0}{284-82.5} \times 100$

$P_{s c}=81 \%$

The pumping included quantities of supernatant as hidden pockets/layer. A noticeable change in the solids volume $(-10 \mathrm{kgal})$ occurred after removal of the liquid. Salt cakes tend to form irregular surfaces, and occasionally floating crusts and/or pockets form above or around a layer of supernatant.

*Constant--Compensates for capillary and unpumpable height within tank. 
Total S-105 Tank Inventory

1975

- Sludge

- Salt cake

- Supernatant

Total waste

$\begin{array}{r}2 \text { kgal } \\ 539 \text { kgal } \\ 0 \text { kgal } \\ \hline 541 \text { kgal }\end{array}$

1994

$\begin{array}{r}2 \mathrm{kgal} \\ 454 \mathrm{kgal} \\ 0 \mathrm{kgal} \\ \hline 456 \mathrm{kgal}\end{array}$

Total 1 iquid pumped (1975)

Total liquid pumped (1978)

Total projected PLR (field data)

$22.0 \mathrm{kgal}$

$114.3 \mathrm{kgal}$

$18.0 \mathrm{kgal}$

Total supernate removed

Based on data for 1975, salt cake volume, and total liquid pumped plus PLR (field data)

Porosity $\left(P_{\text {sc }}\right)=\frac{\text { Liquid removed }+ \text { PLR }- \text { supernatant removed }}{\text { Volume of salt cake }-82.5^{*}} 100$

$P_{s c}=\frac{136.3+18-0}{539-82.5-55} \times 100$

$P_{\text {sc }}=38 \%$

Major pump failure occurred in 1978 and pumping was halted. Analysis in 1988 determined that the stabilization criteria were met and S-105 was declared stabilized. The salt cake volume was adjusted to reflect the actual salt cake volume that was pumped.

The pumping includes quantities of supernatant as hidden pockets/layer. A noticeable change in the solids volume $(-52 \mathrm{kgal})$ occurred after removal of the liquid. Salt cakes tend to form irregular surfaces, and occasionally floating crusts and/or pockets form above or around a layer of supernatant.

*Constant--Compensates for capillary and unpumpable height within tank. 
Total S-106 Tank Inventory

1978

- Sludge

- Sa7t cake

- Supernatant

Total waste
32 kgal

$580 \mathrm{kga}]$

$\frac{0 \mathrm{kgal}}{612 \mathrm{kgal}}$
1994

$32 \mathrm{kgal}$

$511 \mathrm{kgal}$

$\frac{0 \mathrm{kgal}}{543 \mathrm{kgal}}$
Total Tiquid pumped (1978 - 1980)

Total projected PLR (field data)

Total supernate removed
$99.8 \mathrm{kgal}$

$162.0 \mathrm{kga} 7$

$0.0 \mathrm{kga}]$

Based on data for 1978, salt cake volume, and total liquid pumped plus PLR (field data)

Porosity $_{\text {sc }}\left(P_{\text {sc }}\right)=\frac{\text { Liquid removed }+ \text { PLR }- \text { supernatant removed }}{\text { Volume of salt cake }-82.5^{*}} 100$

$P_{\text {sc }}=\frac{(99.8+0-0}{580-82.5}+\frac{162+0-0)}{511-82.5} \times 100$

$P_{\text {sc }}=58 \%$

The pumping occurred between 1978 and 1980, which included quantities of supernatant as hidden pockets/layer. A noticeable change in the solids volume (-85 kgal) occurred after removal of the 1iquid. Salt cakes tend to form irregular surfaces, and occasionally floating crusts and/or pockets form above or around a layer of supernatant.

The present salt cake volume was used for the porosity calculation for the remaining liquid to be pumped at a later date.

"Constant--Compensates for capillary and unpumpable height within tank. 
WHC-SD-W236A-ES-012

Revision 0

Porosity S-108

(PUMPING 1978 - 1980)

Total S-108 Tank Inventory

1978

1994

- Sludge

- Salt cake

- Supernatant

Total waste

$$
\begin{array}{r}
5 \mathrm{kgal} \\
665 \mathrm{kgal} \\
0 \mathrm{kgal} \\
\hline 670 \mathrm{kgal}
\end{array}
$$

$$
\begin{array}{rl}
5 & \mathrm{kgal} \\
599 & \mathrm{kgal} \\
0 & \mathrm{kgal} \\
\hline 604 \mathrm{kgal}
\end{array}
$$

Total liquid pumped $(1978-\cdot 1980)$

Total projected PLR (field data)

Total supernate removed
$151.6 \mathrm{kgal}$

$105.0 \mathrm{kgal}$

$0.0 \mathrm{kgal}$

Based on data for 1978, salt cake volume, and total liquid pumped plus PLR (field data)

Porosity $_{\text {sc }}\left(P_{\text {sc }}\right)=\frac{\text { Liquid removed }+ \text { PLR }- \text { supernatant removed }}{\text { Volume of salt cake }-82.5^{*}} 100$

$P_{s c}=\frac{(151.6+0-0}{665-82.5}+\frac{105+0-0)}{599-82.5} \times 100$

$P_{\text {sc }}=46 \%$

The pumping occurred between 1978 and 1980, which included quantities of supernatant as hidden pockets/layer. A noticeable change in the solids volume (-66 kgal) occurred after removal of the 1iquid. Salt cakes tend to form irregular surfaces, and occasionally floating crusts and/or pockets form above or around a layer of supernatant. The present salt cake volume was used for the porosity calculation for the remaining liquid to be pumped at a later date.

*Constant--Compensates for capillary and unpumpable height within tank. 
Total S-109 Tank Inventory

1978

- Sludge

- Salt cake

- Supernatant

Total waste
$13 \mathrm{kgal}$

$555 \mathrm{kgal}$

$127 \mathrm{kgal}$

$695 \mathrm{kgal}$
1994

\begin{tabular}{rr}
13 & $\mathrm{kgal}$ \\
555 & $\mathrm{kgal}$ \\
0 & $\mathrm{kgal}$ \\
\hline 568 & $\mathrm{kgal}$
\end{tabular}

Total Tiquid pumped $(1978-1980)$

Total projected PLR (field data)

$111 \mathrm{kgal}$

Total supernate removed

$119 \mathrm{kgal}$

$0 \mathrm{kgal}$

Based on data for 1978, salt cake volume, and total liquid pumped plus PLR (field data)

Porosity $_{\text {sc }}\left(P_{\text {sc }}\right)=\frac{\text { Liquid removed }+P L R-\text { supernatant removed }}{\text { Volume of salt cake }-82.5^{*}} 100$

DATA NOT USED

A large quantity of visible supernatant was pumped. After pumping, a visible change in solids volume has not occurred.

*Constant--Compensates for capillary and unpumpable height within tank. 
Total S-110 Tank Inventory

1979

- Sludge

- Salt cake

- Supernatant

Total waste

\section{$113 \mathrm{kgal}$ \\ $579 \mathrm{kgal}$ \\ $\frac{0 \mathrm{kgal}}{692 \mathrm{kgal}}$}

1994

$113 \mathrm{kgal}$

$277 \mathrm{kgal}$

$\frac{0 \mathrm{kgal}}{390 \mathrm{kgal}}$

Total liquid pumped (1979)

Total projected PLR (field data)

Total supernate removed

$185.9 \mathrm{kgal}$

$103.0 \mathrm{kgal}$

$0.0 \mathrm{kgal}$

Based on data for 1979, salt cake volume, and total liquid pumped plus PLR (field data)

Porosity $\left(P_{s c}\right)=$ Lqd rmvd + PLR $-\left(\right.$ Sludge vol $\left.-66^{*}\right) \times P_{s t}$ - supnate rmvd $\times 100$

$P_{s c}=\frac{(185.9+0-7.5}{579-82.5}+\frac{103+0-7.5)}{277-82.5} \times 100$

$P_{\text {sc }}=85 \%$

The pumping occurred in 1979, which included quantities of supernatant as hidden pockets/layer. A noticeable change in the solids volume $(-302 \mathrm{kgal})$ occurred after removal of the liquid. Salt cakes tend to form irregular surfaces, and occasionally floating crusts and/or pockets form above or around a layer of supernatant.

The present salt cake volume was used for the porosity calculation for the remaining liquid to be pumped at a later date.

*Constant--Compensates for capillary height for sludge within tank.

"Constant--Compensates for capillary and unpumpable height with in tank. 
Total S-111 Tank Inventory

1976

$139 \mathrm{kgal}$

$484 \mathrm{kgal}$

- Salt cake

- Supernatant

Total waste $\frac{0 \mathrm{kgal}}{623 \mathrm{kgal}}$
1994

$139 \mathrm{kgal}$

$447 \mathrm{kgal}$

$\frac{10 \mathrm{kgal}}{596 \mathrm{kgal}}$

Total liquid pumped (1976 - 1980)

Total projected PLR (field data)

Total supernate removed

$3.3 \mathrm{kgal}$

$134.0 \mathrm{kga}]$

$0.0 \mathrm{kga}]$

Based on data for 1976, salt cake volume, and total liquid pumped plus PLR (field data)

Porosity $\left(P_{\text {sc }}\right)=\frac{\text { Liquid removed }+ \text { PLR }- \text { supernatant removed }}{\text { Volume of salt cake }-82.5^{\star}} \times 100$

DATA NOT USED

The quantity of liquid pumped is not sufficient to be meaningful for this study.

*Constant--Compensates for capillary and unpumpable height within tank. 
Total S-112 Tank Inventory

1978

- Sludge

- Sa7t cake

- Supernatant

Total waste
$6 \mathrm{kgal}$

$667 \mathrm{kgal}$

$0 \mathrm{kgal}$

1994

$$
\begin{array}{rl}
6 & \mathrm{kgal} \\
631 & \mathrm{kgal} \\
0 & \mathrm{kgal} \\
\hline 637 & \mathrm{kgal}
\end{array}
$$

Total l'iquid pumped (1978 - 1980)

Total projected PLR (field data)

Total supernate removed

$125.1 \mathrm{kgal}$

$112.0 \mathrm{kgal}$

$0.0 \mathrm{kgal}$

Based on data for 1978, salt cake volume, and total liquid pumped plus PLR (field data)

Porosity $_{s c}\left(P_{s c}\right)=\frac{\text { Liquid removed }+P L R-\text { supernatant removed }}{\text { Volume of salt cake }-82.5^{*}} \times 100$

$P_{s c}=\frac{(125.1+0-0}{667-82.5}+\frac{112+0-0)}{631-82.5} \times 100$

$P_{s c}=41 \%$

The pumping occurred between 1978 and 1980 , which included quantities of supernatant as hidden pockets/layer. A noticeable change in the solids volume ( $-36 \mathrm{kga}$ ) $)$ occurred after removal of the liquid. Salt cakes tend to form irregular surfaces, and occasionally floating crusts and/or pockets form above or around a layer of supernatant.

The present salt cake volume was used for the porosity calculation for the remaining liquid to be pumped at a later date.

*Constant--Compensates for capillary and unpumpable height within tank. 
WHC-SD-W236A-ES-012

Revision 0

Porosity SX-104

(PUMPING 1988 - 1989)

Assumed Leaker

Total SX-104 Tank Inventory

- STudge

- Salt cake

- Supernatant

Total waste
1980

$169 \mathrm{kgal}$

$544 \mathrm{kgal}$

$\frac{0 \mathrm{kgal}}{713 \mathrm{kgal}}$
1994

$169 \mathrm{kgal}$

$445 \mathrm{kgal}$

$\frac{0 \mathrm{kgal}}{614 \mathrm{kgal}}$

Total Tiquid pumped (1988 - 1989)

Total projected PLR (field data)

Total supernate removed

Total liquid leaked

Based on data for 1980 , salt cake volume, and total liquid pumped plus PLR (field data)

Porosity $\left(P_{s c}\right)=$ Lqd rmvd $+P L R-\left(\right.$ Sludge vol $\left.-66^{*}\right) \times P_{s l}$ - supnate rmvd Volume of salt cake $-82.5^{* *}$

$P_{s c}=\frac{(113.2+0-16.5}{544-82.5}+\frac{195+0-16.5)}{445-82.5} \times 100$

$P_{s c}=70 \%$

The pumping occurred between 1988 and 1989, which included quantities of supernatant as hidden pockets/layer. A noticeable change in the solids volume (-99 kgal) occurred after removal of the liquid. Salt cakes tend to form irregular surfaces, and occasionally floating crusts and/or pockets form above or around a layer of supernatant.

The present salt cake volume was used for the porosity calculation for the remaining liquid to be pumped at a later date.

*Constant--Compensates for capillary height for sludge within tank.

${ }^{* *}$ Constant--Compensates for capillary and unpumpable height within tank. 
Total TX-102 Tank Inventory

1977

- Sludge

- Salt cake

- Supernatant

Total waste
2 kgal

$453 \mathrm{kgal}$

$\frac{0 \mathrm{kgal}}{455 \mathrm{kgal}}$

$455 \mathrm{kgal}$
1980

$2 \mathrm{kgal}$

$332 \mathrm{kgal}$

$\frac{0 \mathrm{kgal}}{334 \mathrm{kgal}}$
1994

\begin{tabular}{rl}
2 & $\mathrm{kgal}$ \\
215 & $\mathrm{kgal}$ \\
0 & $\mathrm{kgal}$ \\
\hline $217 \mathrm{kgal}$
\end{tabular}

Total liquid pumped (1977 - 1978)

Total liquid pumped (1980 - 1983)

$93.6 \mathrm{kgal}$

$94.4 \mathrm{kgal}$

$4.5 \mathrm{kgal}$

Total projected PLR (field data)

$0.0 \mathrm{kgal}$

Based on data for 1977 and 1980 , salt cake volume, and total liquid pumped plus PLR (field data)

Porosity $_{\text {sc }}\left(P_{\text {sc }}\right)=\frac{\text { Liquid removed }+P L R-\text { supernatant removed }}{\text { Volume of salt cake }-82.5^{*}} \times 100$

$P_{s c}=\frac{(93.6+0-0}{453-82.5}+\frac{94.4+4.5-0)}{332-82.5} \times 100$

$P_{s c}=64 \%$

The pumping campaigns occurred between 1973 and 1983, which included quantities of supernatant as hidden pockets/layer. Noticeable changes in the solids volume (-121 kgal) and (-117 kgal) occurred from removal of the liquid after each pumping campaign. Salt cakes tend to form irregular surfaces, and occasionally floating crusts and/or pockets form above or around a layer of supernatant.

"Constant--Compensates for capillary and unpumpable height within tank. 


\section{Porosity $T X-103$}

Total TX-103 Tank Inventory
1994

- Sludge TBP

- Salt cake

- Supernatant

Total waste
(STABILIZED 1983)

1980

$\begin{array}{r}3 \mathrm{kgal} \\ 154 \mathrm{kgal} \\ 0 \mathrm{kgal} \\ \hline 157 \mathrm{kga} 7\end{array}$

$$
\begin{array}{rl}
3 & \mathrm{kgal} \\
154 & \mathrm{kgal} \\
0 & \mathrm{kgal} \\
\hline 157 & \mathrm{kgal}
\end{array}
$$

Total liquid pumped (1983)

Total projected PLR (field data)

$68.3 \mathrm{kgal}$

$0.0 \mathrm{kgal}$

Total supernate removed

$0.0 \mathrm{kgal}$

Based on data for 1980 , salt cake volume, and total liquid pumped (field data)

Porosity $_{\text {sc }}\left(P_{\text {sc }}\right)=\frac{\text { Liquid removed }+P L R-\text { supernatant removed }}{\text { Volume of salt cake }-82.5^{*}} \times 100$

DATA NOT USED

A large quantity of visible supernatant was pumped. After pumping, a visible change in solids volume did not occur and the remaining salt cake was not pumped because it met the stabilization requirements.

*Constant--Compensates for capillary and unpumpable height within tank. 
Total TX-105 Tank Inventory

- Sludge

- Salt cake

- Supernatant

Total waste

$$
\begin{array}{r}
8 \mathrm{kgal} \\
601 \mathrm{kgal} \\
0 \mathrm{kgal} \\
\hline 609 \mathrm{kgal}
\end{array}
$$

$$
\begin{array}{rr}
8 & \mathrm{kgal} \\
601 & \mathrm{kgal} \\
0 & \mathrm{kgal} \\
\hline 609 \mathrm{kgal}
\end{array}
$$

Total liquid pumped (1977)

Total liquid pumped (1983)

Total projected PLR (field data)

Total supernate removed

Total liquid leaked (average of 19 Tanks)
$126.0 \mathrm{kgal}$

$121.5 \mathrm{kgal}$

$0.0 \mathrm{kgal}$

$0.0 \mathrm{kga} 1$

$8.0 \mathrm{kgal}$

Based on data for 1977, salt cake volume, and total liquid pumped (field data)

Porosity $_{\text {sc }}\left(P_{\text {sc }}\right)=\frac{\text { Liquid removed }+P L R-\text { supernatant removed }}{\text { Volume of salt cake }-82.5^{*}} 100$

$P_{\text {sc }}=\frac{247.5+0-0}{601-82.5} \times 100$

$\mathrm{P}_{\mathrm{sc}}=48 \%$

Did not include amount leaked

*Constant--Compensates for capillary and unpumpable height within tank. 
Porosity TX-106

Total TX-106 Tank Inventory

- Sludge

- Salt cake

- Supernatant

Total waste
(STABILIZED 1983)

1980

1994

$123 \mathrm{kgal}$

$330 \mathrm{kgal}$

$\frac{0 \mathrm{kgal}}{453 \mathrm{kgal}}$
$148 \mathrm{kgal}$

$305 \mathrm{kgat}$

$\frac{0 \mathrm{kgal}}{453 \mathrm{kgal}}$

Total liquid pumped (1983)

Total projected PLR (field data)

$134.6 \mathrm{kgal}$

$0.0 \mathrm{kgal}$

Total supernate removed

$0.0 \mathrm{kgal}$

Based on data for 1980 , salt cake volume, and total liquid pumped (field data)

Porosity $\left(P_{\text {sc }}\right)=$ Lqd rmvd + PLR - (Sludge vol $\left.-66^{*}\right) \times P_{s t}$ - supnate rmvd Volume of salt cake $-82.5^{\star \star}$

$$
\begin{aligned}
& P_{\text {sc }}=\frac{134.6+0-9.1}{(330-25)-82.5} \times 100 \\
& P_{s c}=56 \%
\end{aligned}
$$

Salt cake volume was adjusted for calculating porosity value to compensate for the impenetrable layer of solids found at $41 / 2 \mathrm{ft}$ from bottom during lancing operation (Swaney 1994).

*** Constant--Compensates for capillary height for sludge within tank.

${ }^{* *}$ Constant--Compensates for capillary and unpumpable height with in tank. 
Porosity TX-108

Total TX-108 Tank Inventory

(STABILIZED 1983)

1977

1994

- Sludge

- Salt cake

- Supernatant

Total waste

$$
\begin{array}{rl}
6 & \mathrm{kgal} \\
75 & \mathrm{kgal} \\
0 & \mathrm{kgal} \\
\hline 81 & \mathrm{kgal}
\end{array}
$$

$$
\begin{array}{rl}
6 & \mathrm{kgal} \\
128 \mathrm{kgal} \\
0 \mathrm{kgal} \\
\hline 134 \mathrm{kgal}
\end{array}
$$

Total liquid pumped (1977 - 1978)

Total liquid pumped (1983)

Total projected PLR (field data)

Total supernate removed

$37.1 \mathrm{kgal}$

$13.7 \mathrm{kgal}$

$0.0 \mathrm{kgal}$

$0.0 \mathrm{kgal}$

Based on data for 1977, salt cake volume, and total liquid pumped

Porosity $_{\text {sc }}\left(P_{\text {sc }}\right)=\frac{\text { Liquid removed }+ \text { PLR }- \text { supernatant removed }}{\text { Volume of salt cake }-82.5^{*}} 100$

DATA NOT USED

The salt cake was pumped during primary stabilization (1977 to 1978) which removed liquid. A solids volume increase occurred before the final pumping for stabilization.

*Constant--Compensates for capillary and unpumpable height within tank. 
Total TX-109 Tank Inventory

1980

1994

- Sludge

- Salt cake

- Supernatant

Total waste

$\begin{array}{r}0 \mathrm{kgal} \\ 450 \mathrm{kgal} \\ 0 . \mathrm{kgal} \\ \hline 450 \mathrm{kgal}\end{array}$

$383 \mathrm{kgal}$

$0 \mathrm{kgal}$

$\frac{0 \mathrm{kgal}}{383 \mathrm{kgal}}$

Total liquid pumped (1977)

Total 1 iquid pumped (1982)

Total projected PLR (field data)

Total supernate removed (field data)

$226.0 \mathrm{kgal}$

$72.3 \mathrm{kga} 1$

$0.0 \mathrm{kgal}$

$0.0 \mathrm{kgal}$

Based on 1980 Projection

Porosity $_{\text {sc }}\left(P_{\text {sc }}\right)=\frac{\text { Liquid removed }+P L R-\text { supernatant removed }}{\text { Volume of salt cake }-82.5^{*}} \times 100$

DATA NOT USED

Tank is classified as sludge tank. The dip tubes are plugged and it is difficult to determine liquid levels. Values were measured using pump baseplate as reference. Data for this study are not meaningful.

${ }^{*}$ Constant--Compensates for capillary and unpumpable height within tank. 
Total TX-110 Tank Inventory

1977

- Sludge

- Salt cake

- Supernatant

Total waste
$37 \mathrm{kgal}$

$531 \mathrm{kgal}$

$\frac{0 \mathrm{kgal}}{568 \mathrm{kgal}}$

1980

1994

$\begin{array}{r}37 \mathrm{kgal} \\ 493 \mathrm{kgal} \\ 0 \mathrm{kgal} \\ \hline 530 \mathrm{kgal}\end{array}$

$37 \mathrm{kgal}$

$425 \mathrm{kgal}$

$\frac{0 \mathrm{kgal}}{462 \mathrm{kgal}}$

Total Tiquid pumped (1978 - 1981)

Total liquid pumped (1982)

Total projected PLR (field data)

Total supernate removed

Total liquid leaked (average of 19 Tanks)

$59.6 \mathrm{kgal}$

$115.4 \mathrm{kgal}$

$0.0 \mathrm{kgal}$

$0.0 \mathrm{kgal}$

$8.0 \mathrm{kgal}$

Based on data for 1977 and 1980, salt cake volume, and total liquid pumped (field data)

Porosity $_{\text {sc }}\left(P_{\text {sc }}\right)=\frac{\text { Liquid removed }+ \text { PLR }- \text { supernatant removed }}{\text { Volume of salt cake }-82.5^{*}} \times 100$

$P_{s c}=\frac{(59.6+0-0}{531-82.5}+\frac{115.4+0-0)}{493-82.5} \times 100$

$P_{s c}=41 \%$

Did not include amount leaked

*Constant-Compensates for capillary and unpumpable height within tank. 
WHC-SD-W236A-ES-012

Revision 0

Porosity TX-111

Total TX-111 Tank Inventory
1994

\begin{tabular}{rl}
43 & $\mathrm{kgal}$ \\
327 & $\mathrm{kgal}$ \\
0 & $\mathrm{kgal}$ \\
\hline $370 \mathrm{kgal}$
\end{tabular}

$148.5 \mathrm{kgal}$

$98.4 \mathrm{kgal}$

$0.0 \mathrm{kgal}$

$33.0 \mathrm{kgal}$

Based on data for 1977 , salt cake volume, and total liquid pumped (field data)

Porosity $_{\text {sc }}\left(P_{\text {sc }}\right)=\frac{\text { Liquid removed }+P L R-\text { supernatant removed }}{\text { Volume of salt cake }-82.5^{*}} \times 100$

$P_{s c}=\frac{246.9+0-33.0}{327-82.5} \times 100$

$P_{\text {sc }}=87 \%$

"Constant--Compensates for capillary and unpumpabie height within tank. 
Total TX-112 Tank Inventory

- Sludge

- Salt cake

- Supernatant

Total waste
$24 \mathrm{kgal}$

$625 \mathrm{kgal}$

$\frac{0 \mathrm{kgal}}{649 \mathrm{kgal}}$
$24 \mathrm{kgal}$

$625 \mathrm{kga} 1$

$\frac{0 \mathrm{kgal}}{649 \mathrm{kgal}}$

Total liquid pumped (1978)

Total liquid pumped (1982)

Total projected PLR (field data)

Total supernate removed

$48.1 \mathrm{kgal}$

$94.0 \mathrm{kgal}$

$0.0 \mathrm{kgal}$

$0.0 \mathrm{kgal}$

Based on data for 1977 , salt cake volume, and total liquid pumped (field data)

Porosity $_{s c}\left(P_{s c}\right)=\frac{\text { Liquid removed }+P L R-\text { supernatant removed }}{\text { Volume of salt cake }-82.5^{*}} \times 100$

$P_{s c}=\frac{142.1+0-0}{(625-89)-82.5} \times 100$

$P_{\text {sc }}=31 \%$

Pumping was stopped because of major pump failure and tank met stabilization requirements. The salt cake was adjusted to compensate for the high final liquid level (62.5 in.).

*Constant--Compensates for capillary and unpumpable height within tank. 
Revision 0

Porosity TX-113

Total TX-113 Tank Inventory

- Sludge

- Salt cake

- Supernatant

Total waste
1975

$$
\begin{array}{r}
183 \mathrm{kgal} \\
498 \mathrm{kgal} \\
0 \mathrm{kgal} \\
\hline 681 \mathrm{kgal}
\end{array}
$$

1994

$183 \mathrm{kgal}$ $424 \mathrm{kgal}$

$\frac{0 \mathrm{kgal}}{607 \mathrm{kgal}}$

Total 1iquid pumped (1977)

Total Tiquid pumped (1982)

Total projected PLR (field data)

Total supernate removed

Total liquid leaked (average of 19 Tanks)

$214.3 \mathrm{kgal}$

$19.2 \mathrm{kgal}$

$0.0 \mathrm{kgal}$

$0.0 \mathrm{kga}]$

$8.0 \mathrm{kgal}$

Based on data for 1975, salt cake volume, and total liquid pumped (field data)

Porosity $\left(P_{s c}\right)=$ Lqd rmvd + PLR - (Sludge vol $\left.-66^{*}\right) \times P_{s l^{-}}$supnate rmvd . Volume of salt cake $-82.5^{* *}$

$$
\begin{aligned}
& P_{\text {sc }}=\frac{233.5+0-18.7}{498-82.5} \times 100 \\
& P_{\text {sc }}=52 \%
\end{aligned}
$$

Did not include amount leaked.

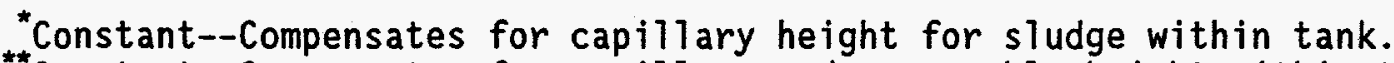

** Constant--Compensates for capillary and unpumpable height within tank. 
Revision 0

Porosity TX-114

Total TX-114 Tank Inventory
1975

- Sludge

- Salt cake

- Supernatant

Total waste

\begin{tabular}{rl}
62 & $\mathrm{kgal}$ \\
616 & $\mathrm{kgal}$ \\
0 & $\mathrm{kgal}$ \\
\hline $678 \mathrm{kgal}$
\end{tabular}

Total liquid pumped (1977)

Total liquid pumped (1982)

Total projected PLR (field data)

Total supernate removed

Total 1iquid leaked (average of 19 Tanks)
1980

1994

\begin{tabular}{rl}
62 & $\mathrm{kgal}$ \\
583 & $\mathrm{kgal}$ \\
0 & $\mathrm{kgal}$ \\
\hline $645 \mathrm{kgal}$
\end{tabular}

$164.5 \mathrm{kgal}$

$104.3 \mathrm{kgal}$

$4.0 \mathrm{kgal}$

$0.0 \mathrm{kgal}$

$8.0 \mathrm{kgal}$

Based on data for 1975 and 1980, salt cake volume, and total liquid pumped (field data)

Porosity $_{\text {sc }}\left(P_{\text {sc }}\right)=\frac{\text { Liquid removed }+ \text { PLR }- \text { supernatant removed }}{\text { Volume of salt cake }-82.5^{\star}} 100$

$P_{s c}=\frac{(164.5+0-0}{616-82.5}+\frac{104.3+4.0-0)}{583-82.5} \times 100$

$P_{\text {se }}=53 \%$

Did not include amount leaked.

The pumping campaigns occurred between 1975 and 1983, which included quantities of supernatant as hidden pockets/layer. Noticeable changes. in the solids volume $(-33 \mathrm{kgal})$ and $(-110 \mathrm{kgal})$ occurred from removal of the liquid after each pumping campaign. Salt cakes tend to form irregular surfaces, and occasionally floating crusts and/or pockets form above or around a layer of supernatant.

${ }^{*}$ Constant--Compensates for capillary and unpumpable height within tank. 
Total TX-115 Tank Inventory

1977

- Sludge

- Salt cake

- Supernatant Total waste
$8 \mathrm{kgal}$

$632 \mathrm{kgal}$

$\frac{0 \mathrm{kgal}}{640 \mathrm{kgal}}$
1994

$$
\begin{array}{r}
8 \mathrm{kgal} \\
632 \mathrm{kgal} \\
0 \mathrm{kgal} \\
\hline 640 \mathrm{kgal}
\end{array}
$$

Total liquid pumped (1978)

Total Tiquid pumped (1983)

Total projected PLR (field data)

Total supernate removed

Total liquid leaked (average of 19 Tanks)

$10.7 \mathrm{kga} 7$

$99.1 \mathrm{kgal}$

$0.0 \mathrm{kgal}$

$0.0 \mathrm{kgal}$

$8.0 \mathrm{kgal}$

Based on data for 1977, salt cake volume, and total liquid pumped

Porosity $_{\text {sc }}\left(P_{\text {sc }}\right)=\frac{\text { Liquid removed }+ \text { PLR }- \text { supernatant removed }}{\text { Volume of salt cake }-82.5^{*}} \times 100$

DATA NOT USED

Records for 1 iquids pumped in 1977 for primary stabilization are not consistent with amounts of liquids removed from other tanks.

*Constant--Compensates for capillary and unpumpable height within tank. 
Total TX-116 Tank Inventory

1976

- Sludge

- Salt cake

- Supernatant

Total waste
$20 \mathrm{kgal}$

$611 \mathrm{kgal}$

$\frac{0 \mathrm{kgal}}{631 \mathrm{kgal}}$
1994

$$
\begin{array}{r}
20 \mathrm{kgal} \\
611 \mathrm{kgal} \\
0 \mathrm{kgal} \\
\hline 631 \mathrm{kgal}
\end{array}
$$

Total liquid pumped (1977)

Total liquid pumped (1982)

Total projected PLR (field data)

Total supernate removed

Total liquid leaked (average of 19 Tanks)
$195.5 \mathrm{kgal}$

$23.9 \mathrm{kgal}$

$0.0 \mathrm{kga}]$

$0.0 \mathrm{kgal}$

$8.0 \mathrm{kgal}$

Based on data for 1976, salt cake volume, and total liquid pumped (field data)

Porosity $_{\text {sc }}\left(P_{\text {sc }}\right)=\frac{\text { Liquid removed }+P L R-\text { supernatant removed }}{\text { Volume of salt cake }-82.5^{*}} 100$

DATA NOT USED

Diatomaceous earth and desiccant had been added to tank as an effort to control leaking.

A 15-in. spool piece was installed under the pump with 13 in. of solids in the salt well screen when pumping was shut down. Final liquid level was at 52 in.

*Constant--Compensates for capillary and unpumpable height within tank. 
Total TX-117 Tank Inventory

1977

- Sludge

- Salt cake

- Supernatant

Total waste \begin{tabular}{rr}
7 & $\mathrm{kgal}$ \\
619 & $\mathrm{kgal}$ \\
0 & $\mathrm{kgal}$ \\
\hline 626 & $\mathrm{kgal}$
\end{tabular}

Total liquid pumped (1977)

Total liquid pumped (1982)

Total projected PLR (field data)

Total supernate removed

Total liquid leaked (average of 19 Tanks)
1994

$$
\begin{array}{r}
7 \mathrm{kgal} \\
619 \mathrm{kgal} \\
0 \mathrm{kgal} \\
\hline 626 \mathrm{kga} 7
\end{array}
$$

Based on data for 1977, salt cake volume, and total liquid pumped (field data)

Porosity $_{\text {sc }}\left(P_{\text {sc }}\right)=\frac{\text { Liquid removed }+ \text { PLR }- \text { supernatant removed }}{\text { Volume of salt cake }-82.5^{*}} \times 100$

DATA NOT USED

Diatomaceous earth and desiccant had been added to tank as an effort to control leaking.

The dip tubes were plugged and could not measure liquid level. Used measurements based on pump location.

*Constant--Compensates for capillary and unpumpable height within tank. 
WHC-SD-W236A-ES-012

Revision 0

Porosity TX-118

(STABILIZED 1983)

Total TX-118 Tank Inventory

1980

1994

- Sludge

- Salt cake

- Supernatant Total waste

\begin{tabular}{rl}
33 & $\mathrm{kgal}$ \\
314 & $\mathrm{kgal}$ \\
0 & $\mathrm{kgal}$ \\
\hline $347 \mathrm{kgal}$
\end{tabular}

$33 \mathrm{kgal}$

$314 \mathrm{kgal}$

$\frac{0 \mathrm{kgal}}{347 \mathrm{kgal}}$

Total liquid pumped (1983)

Total projected PLR (field data)

Total supernate removed

$89.1 \mathrm{kgal}$

$0.0 \mathrm{kgal}$

$0.0 \mathrm{kgal}$

Based on data for 1980 , salt cake volume, and total liquid pumped (field data)

Porosity $_{\text {sc }}\left(P_{\text {sc }}\right)=\frac{\text { Liquid removed }+P L R-\text { supernatant removed }}{\text { Volume of salt cake }-82.5^{*}} 100$

$P_{s c}=\frac{89.1+0-0}{314-82.5} \times 100$

$P_{\text {sc }}=38 \%$

*Constant--Compensates for capillary and unpumpable height within tank. 
Total BX-109 Tank Inventory

1990

\begin{tabular}{rr}
193 & $\mathrm{kgal}$ \\
0 & $\mathrm{kgal}$ \\
5 & $\mathrm{kgal}$ \\
\hline 198 & $\mathrm{kgal}$
\end{tabular}
1994

- Sludge

- Salt cake

- Supernatant Total waste
Total 1 iquid pumped

Total projected PLR (field data)

Total supernate removed
$193 \mathrm{kgal}$

$0 \mathrm{kgal}$

$\frac{0 \mathrm{kgal}}{193 \mathrm{kgal}}$

Based on data for 1990 , sludge cake volume, and total liquid pumped plus PLR (field data)

Porosity $_{\text {se }}\left(P_{s c}\right)=\frac{\text { Liquid removed }+ \text { PLR }- \text { supernatant removed }}{\text { Volume of sludge }-115.5^{\star}} \times 100$

$P_{s c}=\frac{12.8+7.6-4.6}{193-115.5} \times 100$

$P_{\text {sc }}=20 \%$

"Constant--Compensates for capillary and unpumpable height within tank.

$12.8 \mathrm{kgal}$

$7.6 \mathrm{kgal}$

$4.6 \mathrm{kgal}$ 
Total BX-112 Tank Inventory

- Sludge

- Salt cake

- Supernatant

Total waste
1990

164. $\mathrm{kgal}$

$0 \mathrm{kgal}$

$\frac{1 \mathrm{kgal}}{165 \mathrm{kgal}}$
1994

$164 \mathrm{kgal}$

$0 \mathrm{kgal}$

$\frac{1 \mathrm{kgal}}{165 \mathrm{kgal}}$

Total liquid pumped

Total projected PLR (field data)

$4.1 \mathrm{kgal}$

Total supernate removed

$2.1 \mathrm{kgal}$

$0.0 \mathrm{kgal}$

Based on data for 1990, sludge cake volume, and total liquid pumped plus PLR (field data)

Porosity $_{\text {sc }}\left(P_{\text {sc }}\right)=\frac{\text { Liquid removed }+P L R-\text { supernatant removed }}{\text { Volume of sludge }-115.5^{*}} \times 100$

$P_{\text {sc }}=\frac{4.1+2.1-0}{164-115.5} \times 100$

$P_{\text {sc }}=13 \%$

"Constant--Compensates for capillary and unpumpable height within tank. 
Porosity $\mathrm{C}-102$

Total C-102 Tank Inventory

- Sludge

- Salt cake

- Supernatant

Total waste
1991

(PUMPING)

$$
\begin{array}{rr}
423 & \mathrm{kgal} \\
0 & \mathrm{kgal} \\
0 & \mathrm{kgal} \\
\hline 423 & \mathrm{kgal}
\end{array}
$$

1994

$423 \mathrm{kgal}$

$0 \mathrm{kgal}$

$\frac{0 \mathrm{kgal}}{423 \mathrm{kgal}}$
Total liquid pumped

Total projected PLR (field data)

Total supernate removed
$14.2 \mathrm{kgal}$

$23.6 \mathrm{kgal}$

$0.0 \mathrm{kgal}$

Based on data for 1991, sludge cake volume, and total liquid pumped plus PLR (field data)

Porosity $_{\text {sc }}\left(P_{\text {sc }}\right)=\frac{\text { Liquid removed }+ \text { PLR - supernatant removed }}{\text { Volume of sludge }-115.5^{*}} \times 100$

$P_{s c}=\frac{14.2+23.6-0}{423-115.5} \times 100$

$P_{\text {sc }}=12 \%$

*Constant--Compensates for capillary and unpumpabie height within tank. 
WHC-SD-W236A-ES-012

Revision 0

Porosity $\mathrm{C}-107$

Total C-107 Tank Inventory

- Sludge

- Salt cake

- Supernatant Total waste

Total liquid pumped

Total projected PLR (field data)

Total supernate removed
(PUMPING)

1991

1994

$275 \mathrm{kgal}$

$0 \mathrm{kgal}$

$\frac{0 \mathrm{kgal}}{275 \mathrm{kgal}}$
$275 \mathrm{kgal}$

$0 \mathrm{kgal}$

$\frac{0 \mathrm{kgal}}{275 \mathrm{kgal}}$

Based on data for 1991, sludge cake volume, and total liquid pumped plus PLR (field data)

Porosity $_{\text {sc }}\left(P_{\text {sc }}\right)=\frac{\text { Liquid removed }+P L R-\text { supernatant removed }}{\text { Volume of sludge }-115.5^{*}} \times 100$

$P_{s c}=\frac{17.9+18.5-0}{275-115.5} \times 100$

$P_{s c}=23 \%$

*Constant--Compensates for capillary and unpumpable height within tank.

$17.9 \mathrm{kgal}$

$18.5 \mathrm{kgal}$

$0.0 \mathrm{kgal}$ 
Total C-110 Tank Inventory

1991

$187 \mathrm{kgal}$

$0 \mathrm{kgal}$

$\frac{0 \mathrm{kgal}}{187 \mathrm{kgal}}$
1994

$187 \mathrm{kga} 7$

$0 \mathrm{kgal}$

$\frac{0 \mathrm{kgal}}{187 \mathrm{kgal}}$

Total liquid pumped

Total projected PLR (field data)

Total supernate removed

Total volume leaked

$12.4 \mathrm{kgal}$

$2.0 \mathrm{kgal}$

$0.0 \mathrm{kgal}$

$2.0 \mathrm{kgal}$

Based on data for 1991, sludge cake volume, and total liquid pumped plus PLR (field data)

Porosity $_{\text {sc }}\left(P_{\text {sc }}\right)=\frac{\text { Liquid removed }+ \text { PLR }- \text { supernatant removed }}{\text { Volume of sludge }-115.5^{*}} \times 100$

$P_{s c}=\frac{12.4+2-0}{187-115.5} \times 100$

$P_{\text {sc }}=19 \%$

*Constant--Compensates for capillary and unpumpable height within tank. 
Total T-111 Tank Inventory

1993

$$
\begin{array}{rl}
453 & \mathrm{kgal} \\
0 & \mathrm{kgal} \\
0 & \mathrm{kgal} \\
\hline 453 & \mathrm{kgal}
\end{array}
$$

1995

$446 \mathrm{kga} 7$

0 kgal

$\frac{0 \mathrm{kgal}}{446 \mathrm{kgal}}$

Total liquid pumped

Total projected PLR (field data)

Total supernate removed

$9.6 \mathrm{kgal}$

Total volume leaked (less than)

Based on data for 1993, sludge cake volume, and total liquid pumped plus PLR (field data)

Porosity $_{\text {sc }}\left(P_{\text {sc }}\right)=\frac{\text { Liquid removed }+P L R-\text { supernatant removed }}{\text { Volume of sludge }-115.5^{*}} \times 100$

$P_{s c}=\frac{9.6+29.1-0}{453-115.5} \times 100$

$P_{\text {sc }}=11 \%$

*Constant--Compensates for capillary and unpumpable height within tank. 


\section{WHC-SD-W236A-ES-012 \\ Revision 0}

\section{A1.0 REFERENCES}

Swaney, S. L., 1994, Single Shell Tank Stabilization Record, WHC-SD-RE-TI-178, Rev. 4, Westinghouse Hanford Company, Richland, Washington.

\section{A2.0 GLOSSARY}

\section{ABBREVIATIONS AND ACRONYMS}

Lqd Tiquid

rmvd removed

supnate supernatant

Vol volume 
WHC-SD-W236A-ES-012

Revision 0

APPENDIX B

SINGLE-SHELL TANK POROSITY DATABASE

B-1 
WHC-SD-W236A-ES-012

Revision 0

This page intentionally left blank.

B-2 
Table B-1. Single-She11 Tank Salt Cake Porosity Database.

\begin{tabular}{|c|c|c|c|c|c|c|c|c|}
\hline TANK & TOTAL & SLUDGE & SLTCAKE & SUPER- & TOT LIQUID & PUMPABLE & TOT LIQUIO & POROSITY \\
\hline No. & WASTE & & & NATANT & PUMPED & LIQUID REMAIN & SC/SL & VALUE \\
\hline & ( $\mathrm{K}$ gal) & (K gal) & I $\mathrm{K}$ gall & ( $K$ gal) & ( $\mathrm{K}$ gal) & ( $\mathrm{K}$ gall) & (K gal) & $\%$ \\
\hline$B X-111$ & 233 & 32 & 179 & 33 & 119.1 & 이 & 119.1 & 89 \\
\hline BY-101 & 439 & 37 & 402 & o) & 97.4 & 0 & 97.4 & 30 \\
\hline BY-102 & 417 & 29 & 388 & 이 & 186 & 6.7 & 192.7 & 63 \\
\hline BY-103 & 461 & 9 & 452 & 0 & 162.9 & 137 & 299.9 & 81 \\
\hline BY-104 & 634 & 150 & 473 & 11 & 329.5 & o & 329.5 & 82 \\
\hline BY-107 & 367 & 117 & 250 & 0 & 209.5 & 0 & 209.5 & 100 \\
\hline BY.109 & 433 & 36 & 397 & o) & 117.4 & 43.2 & 160.6 & 51 \\
\hline$B Y-110$ & 508 & 190 & 315 & 3 & 213.3 & o) & 213.3 & 90 \\
\hline$B Y-111$ & 615 & 26 & 589 & 이 & 341.4 & 이 & 341.4 & 67 \\
\hline BY-112 & 310 & 26 & 284 & 0 & 163.3 & 0 & 163.3 & 81 \\
\hline S-105 & 541 & 2 & 539 & 0 & 136.3 & 18 & 154.3 & 38 \\
\hline S-106 & $612 / 543^{\circ}$ & 32 & $580 / 511^{*}$ & 이 & 99.8 & 162 & 261.8 & 58 \\
\hline S-108 & $670 / 604^{\circ}$ & 5 & $665 / 599^{*}$ & 이 & 151.6 & 105 & 256.6 & 46 \\
\hline s.110 & $692 / 390^{\circ}$ & 113 & $579 / 277^{\circ}$ & 01 & 185.9 & 103 & 288.9 & 90 \\
\hline S-112 & $673 / 637^{\prime \prime}$ & 6 & $667 / 631^{\circ}$ & 0 & 125.1 & 11.2 & 237.1 & 41 \\
\hline $5 \times-104$ & $713 / 614^{*}$ & 169 & $544 / 445^{\prime}$ & o) & 113.2 & 195 & 308.2 & 79 \\
\hline$T X-102$ & $455 / 334^{*}$ & 2 & $453 / 332^{\circ}$ & 0 & 188 & 4.5 & 192.5 & 64 \\
\hline$T X-105$ & 609 & 8 & 601 & o & 247.5 & 0 & 247.5 & 48 \\
\hline$T X-106$ & 453 & 123 & $330-25 \cdots$ & 이 & 134.6 & 0 & 134.6 & 60 \\
\hline $\mathrm{TX} \cdot 110$ & $568 / 530^{\circ}$ & 37 & $531 / 493^{\circ}$ & 이 & 175 & o & 175 & 41 \\
\hline$T X .111$ & 403 & 43 & 327 & 33 & 246.9 & 0 & 246.9 & 87 \\
\hline$T X-112$ & 649 & 24 & $625-89^{\prime \prime}$ & 이 & 142.1 & 0 & 142.1 & 31 \\
\hline$T \times-113$ & 681 & 183 & 498 & o) & 233.5 & o) & 233.5 & 56 \\
\hline TX-114 & $678 / 645^{\prime \prime}$ & $\therefore \quad 62$ & $616 / 583^{\circ}$ & 0 & 268.8 & 4 & 272.8 & 53 \\
\hline$T X-118$ & 347 & 33 & 314 & 0 & 89.1 & o & 89.1 & 38 \\
\hline \multicolumn{9}{|c|}{ - Waste Volume Updated } \\
\hline *Was & Volume & Adjusted $F$ & Ending Li & uid Levell & & & & \\
\hline
\end{tabular}




\section{WHC-SD-W236A-ES-012 \\ Revision 0}

Table B-2. Single-She11 Tank Sludge Porosity Database.

\begin{tabular}{|c|c|c|c|c|c|c|c|c|}
\hline TANK & TOTAL & SLUDGE & SLTCAKE & SUPER- & TOT LIQUID & PUMPABLE & TOT LIQUID & POROSITY \\
\hline No. & WASTE & & & NATANT & PUMPED & LIQUID REMAIN & SC/SL & VALUE \\
\hline & ( $\mathrm{K}$ gall & | $\mathrm{K}$ gall & ( $\mathrm{K}$ gall) & ( $\mathrm{K}$ gall) & ( $\mathrm{K}$ gal) & I $\mathrm{Kgail}$ & ( $\mathrm{K}$ gal) & $\%$ \\
\hline$B X-109$ & 193 & 193 & 0 & ol & $12.8^{*}$ & 7.6 & 158 & 20 \\
\hline$B X-112$ & 165 & 164 & ol & 1 & 4.1 & 21 & 6.2 & 13 \\
\hline C-102 & 423 & 423 & 0 & 0 & 14.2 & 23.6 & 37.8 & 12 \\
\hline C-107 & 275 & 275 & 0 & 0 & 17.9 & 18.5 & 36.4 & 23 \\
\hline C-110 & 187 & 187 & 0 & 0 & 12.4 & 2 & 13.9 & 19 \\
\hline $\mathrm{T}-111$ & 453 & 453 & 0 & ol & 9.6 & 29.1 & 38.7 & 11 \\
\hline
\end{tabular}


WHC-SD-W236A-ES-012
Revision 0

APPENDIX C

POROSITY PROJECTION COMPARISON 


\section{WHC-SD-W236A-ES-012}

Revision 0

This page intentionally left blank.

$\mathrm{C}-2$ 
Revision 0

Table C-1. Salt Cake Porosity Projection Comparison.

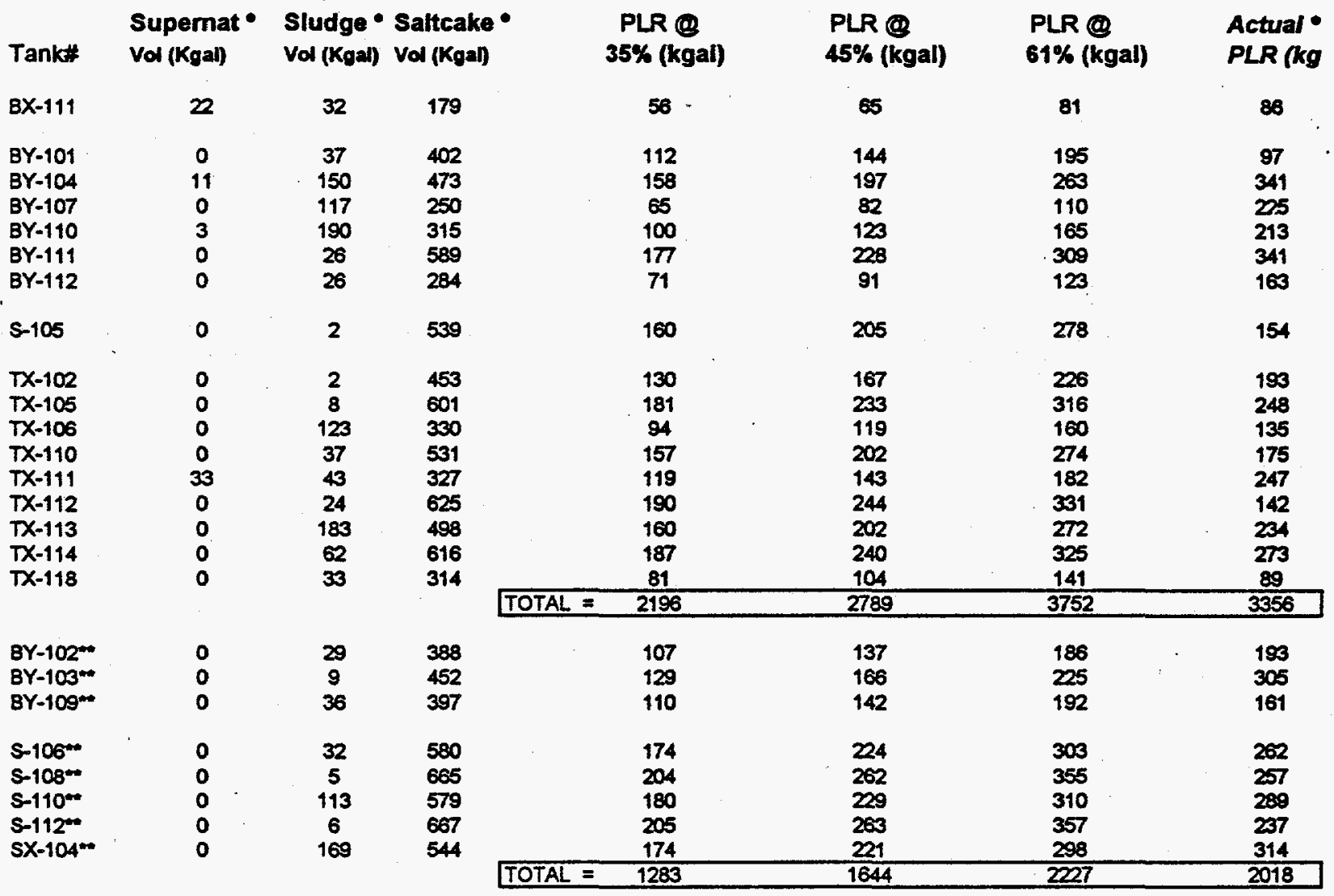

\begin{tabular}{|l|l|l|l|l|l|l|}
\hline TOTAL & 3479 & & 4333 & & 5979 & \\
\hline
\end{tabular}

The $35 \%$ porosity value under estimates the actual pumpable liquid volume by $1895 \mathrm{Kgals}$

The $45 \%$ porosity value under estimates the actual pumpable liquid volume by $941 \mathrm{Kgals}$.

The $61 \%$ porosity value over estimates the actual pumpable liquid volume by $605 \mathrm{Kgals}$

\footnotetext{
- Supernate, studge, and salt cake volumes taken from pre-pumping estimates

- Indicates pumping started but not complete

Vokume of liquid wasto in tenk before eny pumping took place.

Determined by adding tha volume of lapid waste removed to the volume of lipuid waste estimeted to be remeining.
} 
WHC-SD-W236A-ES-012

Revision 0

Table C-2. Sludge Tank Porosity Projection Comparison.

\begin{tabular}{|c|c|c|c|c|c|c|}
\hline Tank \# & $\begin{array}{l}\text { Supernat } \\
\text { Vol (Kgal) }\end{array}$ & $\begin{array}{l}\text { Sludge } \\
\text { Vol (Kgal) }\end{array}$ & $\begin{array}{l}\text { Saltcake } \\
\text { Vol (Kgal) }\end{array}$ & $\begin{array}{c}\text { PLR @ } \\
12.5 \%\end{array}$ & $\begin{array}{c}\text { PLR @ } \\
16 \%\end{array}$ & $\begin{array}{l}\text { Actual } \\
P L R\end{array}$ \\
\hline $\begin{array}{l}\text { BX-109 } \\
\text { BX-112 }\end{array}$ & $\begin{array}{l}0 \\
1\end{array}$ & $\begin{array}{l}193 \\
164\end{array}$ & $\begin{array}{l}0 \\
0\end{array}$ & $\begin{array}{c}10 \\
7\end{array}$ & $\begin{array}{c}12 \\
9\end{array}$ & $\begin{array}{c}20 \\
6\end{array}$ \\
\hline $\begin{array}{l}\text { C-102 } \\
\text { C-107" } \\
\text { C-110"* }\end{array}$ & $\begin{array}{l}3 \\
0 \\
5\end{array}$ & $\begin{array}{l}423 \\
275 \\
187\end{array}$ & $\begin{array}{l}0 \\
0 \\
0\end{array}$ & $\begin{array}{l}41 \\
20 \\
14\end{array}$ & $\begin{array}{l}52 \\
26 \\
16\end{array}$ & $\begin{array}{l}38 \\
36 \\
16\end{array}$ \\
\hline \multirow[t]{2}{*}{$T-111$} & 0 & 453 & 0 & 42 & 54 & 40 \\
\hline & & & & 134 & 169 & 156 \\
\hline
\end{tabular}

The $12.5 \%$ sludge porosity under estimates the actual pumpable liquid volume by 22 kgals.

The $16 \%$ sludge porosity over estimates the actual pumpable liquid volume by $13 \mathrm{kgals}$.

1

Supernate, sludge, and salt cake volumes taken from pre-pumping estimates
Indicates pumping started but not complete
Volume of liquid waste in tank before any pumping took place.
Determined by adding the volume of liquid waste removed to the volume of liquid waste estimated to be remaining. 
WHC-SD-W236A-ES-012

Revision 0

APPENDIX D

UNSTABILIZED SINGLE-SHELL TANK LIQUID INVENTORY

D-1 
WHC-SD-W236A-ES-012

Revision 0

This page intentionally left blank. 
Table D-1. Unstabilized Single-She11 Tank Liquid Inventory Comparisons.

\begin{tabular}{|c|c|c|c|c|c|c|c|}
\hline TANK & TOTAL & SLUDGE & SALTCAKE & SUPER- & SC- $63 \%$ & SC-35\% * & SC-45\%" \\
\hline & WASTE & & & NATANT & SL-16\% & SL-12.5\% & SL-12.5\% \\
\hline & (K gal) & ( $\mathrm{K}$ gall) & IK gall & (K gal) & (K gal) & (K gal) & (K gal) \\
\hline$A-101$ & 953 & 3 & 950 & 0 & 547 & 304 & 390 \\
\hline$A X-101$ & 748 & 13 & 735 & 0 & 411 & 232 & 298 \\
\hline $8 X-106$ & 46 & 31 & 0 & 15 & 15 & 15 & 15 \\
\hline BY $-102 *$ & 341 & 0 & 341 & 0 & 7 & 7 & 7 \\
\hline BY $-103^{*}$ & 400 & 9 & 391 & 0 & 137 & 137 & 137 \\
\hline BY-105 & 503 & 166 & 337 & 0 & 176 & 132 & 169 \\
\hline BY-106 & 642 & 98 & 544 & 0 & 296 & 166 & 213 \\
\hline BY-109* & 423 & 36 & 387 & 0 & 43 & 43 & 43 \\
\hline$C-102^{*}$ & 423 & 423 & 0 & 0 & 24 & 24 & 24 \\
\hline$C-103^{*}$ & 195 & 62 & 0 & 133 & 133 & 133 & 133 \\
\hline C-105 & 150 & 150 & 0 & 0 & 6 & 4 & 8 \\
\hline C-106 & 229 & 197 & 0 & 32 & 45 & 42 & 42 \\
\hline C-107 & 275 & 275 & 0 & 0 & 19 & 19 & 19 \\
\hline C. $110^{\circ}$ & 187 & 187 & 0 & 0 & 2 & 2 & 2 \\
\hline S-101 & 427 & 211 & 204 & 12 & 112 & 65 & 90 \\
\hline S-102 & 549 & 4 & 545 & 0 & 291 & 162 & 208 \\
\hline S-103 & 248 & 9 & 222 & 17 & 105 & 66 & 79 \\
\hline$S-106^{*}$ & 547 & 32 & 511 & 4 & 168 & 168 & 168 \\
\hline S-107 & 376 & 212 & 150 & 14 & 80 & 30 & 52 \\
\hline S-108* & 604 & 5 & 599 & 0 & 105 & 105 & 105 \\
\hline S-109* & 568 & 13 & 555 & 0 & 119 & 119 & 119 \\
\hline S.110 & 390 & 113 & 277 & 0 & 103 & 103 & 103 \\
\hline$S-111^{*}$ & 596 & 139 & 447 & 10 & 134 & 134 & 134 \\
\hline$S-112^{*}$ & 637 & 6 & 631 & 0 & 107 & 107 & 107 \\
\hline $5 x-101$ & 456 & 403 & 52 & 1 & 47 & 98 & 124 \\
\hline $5 x-102$ & 543 & 59 & 484 & 0 & 253 & 127 & 177 \\
\hline $5 x-103$ & 652 & 112 & 539 & 1 & 296 & 192 & 211 \\
\hline $5 x-104^{*}$ & 614 & 169 & 445 & 0 & 195 & 195 & 195 \\
\hline $5 x-105$ & $683^{\prime}$ & 55 & 628 & 0 & 344 & 186 & 238 \\
\hline Sx-106 & 538 & 6 & 476 & 61 & 309 & 195 & 233 \\
\hline$T-104$ & 445 & 442 & 0 & 3 & 55 & 44 & 44 \\
\hline$T-107$ & 180 & 171 & 0 & 9 & 18 & 16 & 16 \\
\hline$T-110$ & 379 & 376 & 0 & 3 & 45 & 36 & 36 \\
\hline$U-102$ & 374 & 43 & 313 & 18 & 163 & 99 & 122 \\
\hline$U-103$ & 468 & 32 & 423 & 13 & 228 & 132 & 166 \\
\hline U-105 & 418 & 32 & 349 & 37 & 205 & 130 & 157 \\
\hline U-106 & 226 & 26 & 185 & 15 & 80 & 51 & 61 \\
\hline U-107 & 406 & 90 & 285 & 31 & 162 & 128 & 156 \\
\hline U-108 & 468 & 26 & 415 & 24 & 233 & 64 & 174 \\
\hline U.109 & 463 & 48 & 396 & 19 & 217 & 147 & 160 \\
\hline U-111 & 329 & 26 & 303 & 0 & 139 & 77 & 99 \\
\hline TOTALS & 18099 & 4510 & 13119 & 472 & 6172 & 4235 & 5034 \\
\hline
\end{tabular}


Table D-2. UnstabiTized Single-Shell Tank Liquid Inventory.

\begin{tabular}{|c|c|c|c|c|c|c|c|}
\hline TANK & TOTAL & SLUDGE & SLTCAKE & SUPER- & BASE & FLUSH & TOTAL \\
\hline & WASTE & & & NATANT & SC-63\% & WATER & LIQUID to DST's \\
\hline & (K gal) & (K gal) & ( $\mathrm{K}$ gal) & (K gal) & SL-16\% & (K gal) & (K gal) \\
\hline & & & & & ( K gal) & & \\
\hline & & & & & & & \\
\hline A-101 & 953 & 3 & 950 & 0 & 547 & 142 & 689 \\
\hline$A X-101$ & 748 & 13 & 735 & 0 & 411 & 107 & 518 \\
\hline $8 X-106$ & 46 & 31 & 0 & 15 & 15 & 4 & 19 \\
\hline $\mathrm{BY}-102^{\circ}$ & 341 & 0 & 341 & 0 & 7 & 2 & 9 \\
\hline BY $-103^{*}$ & 400 & 9 & 391 & 0 & 137 & 36 & 173 \\
\hline BY-105 & 503 & 166 & 337 & 0 & 176 & 46 & 222 \\
\hline BY-106 & 642 & 98 & 544 & 0 & 296 & 77 & 373 \\
\hline BY $-109^{\circ}$ & 423 & 36 & 387 & 0 & 43 & 11 & 54 \\
\hline $\mathrm{C}-102^{*}$ & 423 & 423 & 0 & 0 & 24 & 6 & 30 \\
\hline$c-103^{\circ}$ & 195 & 62 & 0 & 133 & 133 & 35 & 168 \\
\hline $\mathrm{C}-105$ & 150 & 150 & 0 & 0 & 6 & 1 & 7 \\
\hline C.106 & 229 & 197 & 0 & 32 & 45 & 12 & 57 \\
\hline$C-107^{*}$ & 275 & 275 & 0 & 0 & 19 & 5 & 24 \\
\hline $\mathrm{C}-110^{\circ}$ & 187 & 187 & 0 & 0 & 2 & 1 & 3 \\
\hline S-101 & 427 & 211 & 204 & 12 & 112 & 29 & 141 \\
\hline $5-102$ & 549 & 4 & 545 & 0 & 291 & 76 & 367 \\
\hline S-103 & 248 & 9 & 222 & 17 & 105 & 27 & 132 \\
\hline $5-106^{\circ}$ & 547 & 32 & 511 & 4 & 168 & 44 & 212 \\
\hline$s-107$ & 376 & 212 & 150 & 14 & 80 & 21 & 101 \\
\hline $5-108^{*}$ & 604 & 5 & 599 & 0 & 105 & 27 & 132 \\
\hline $5-109^{*}$ & 568 & 13 & 555 & 0 & 119 & 31 & 150 \\
\hline $5-110^{*}$ & 390 & 113 & 277 & 0 & 103 & 27 & 130 \\
\hline $5-111^{\circ}$ & 596 & 139 & 447 & 10 & 134 & 35 & 169 \\
\hline $5-112^{*}$ & 637 & 6 & 631 & 0 & 107 & 28 & 135 \\
\hline $5 x-101$ & 456 & 403 & 52 & 1 & 47 & 12 & 59 \\
\hline $5 x-102$ & 543 & 59 & 484 & 0 & 253 & 66 & 319 \\
\hline $5 x-103$ & 652 & 112 & 539 & 1 & 296 & 77 & 373 \\
\hline $5 x-104^{*}$ & 614 & 169 & 445 & 0 & 195 & 51 & 246 \\
\hline $5 x-105$ & 683 & 55 & 628 & 0 & 344 & 89 & 433 \\
\hline SX-106 & 538 & 6 & 476 & 61 & 309 & 80 & 389 \\
\hline$T-104$ & 445 & 442 & 0 & 3 & 55 & 14 & 70 \\
\hline$T-107$ & 180 & 171 & 0 & 9 & 18 & 5 & 23 \\
\hline$T-110$ & 379 & 376 & 0 & 3 & 45 & 12 & 56 \\
\hline U-102 & 374 & 43 & 313 & 18 & 163 & 42 & 206 \\
\hline U-103 & 468 & 32 & 423 & 13 & 228 & 59 & 287 \\
\hline U-105 & 418 & 32 & 349 & 37 & 205 & 53 & 258 \\
\hline U-106 & 226 & 26 & 185 & 15 & 80 & 21 & 100 \\
\hline$U-107$ & 406 & 90 & 285 & 31 & 162 & 42 & 205 \\
\hline U-108 & 468 & 26 & 415 & 24 & 233 & 61 & 294 \\
\hline$U-109$ & 463 & 48 & 396 & 19 & 217 & 56 & 273 \\
\hline $\mathrm{U}-111$ & 329 & 26 & 303 & 0 & 139 & 36 & 175 \\
\hline TOTALS & 18099 & 4510 & 13119 & 472 & 6172 & 1605 & 7777 \\
\hline
\end{tabular}

- Field Data 
WHC-SD-W236A-ES-012

Revision 0

APPENDIX E

BREAKDOWN OF COMPLEX/NONCOMPLEX

UNSTABILIZED SINGLE-SHELL TANKS 
WHC-SD-W236A-ES-012

Revision 0

This page intentionally left blank. 
WHC-SD-W236A-ES-012

Revision 0

Table E-1. Complex/Noncomplex Single-Shell Tanks Requiring Stabilization. $\cos x+x$

East Area Tanks

$\begin{array}{ll} & \text { Liquid } \\ & \text { Volume } \\ \text { Tank * } \quad \text { (Kgal) }\end{array}$

C-102 sl 24

C-107 sl $\quad 19$

C-110 s! 2

East Area

Complex Total =
West Area Tanks

Liquid
Volume

Tank \# (Kgal)

S-102 282

S-111 * 134

sX-103 $\quad 287$

SX-106 * 301

U-103 * 221

U-105 * 200

U-106 * 78

U-107 158

U-111 135

West Area

Complex

Total =

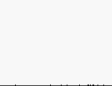

1796

\section{Wor of on}

East Area Tanks

Liquid

Volume

Tank \# (Kgal)

A-101 529

AX-101 398

BX-106 sl 15

BY-102 7

BY-103 137

BY-105 171

BY-106 287

BY-109 43

C-103 sl 133

C-105 sl 6

]C-106 sI 45

\section{East Area}

Non-complex

Total =

1771
West Area Tanks

Tank \# $\begin{aligned} & \text { Liquid } \\ & \text { Volume } \\ & \text { (Kgal) }\end{aligned}$

S-101 109

S-103 102

S-106 168

S-107 79

S-108. 105

S-109 $\quad 119$

S-110 103

S $-112 \quad 107$

SX-101 47

sX-102 $\quad 245$

$s x-104 \quad 195$

$s X-105 \quad 333$

T-104 sl 55

$\mathrm{T}-107 \mathrm{sl} \quad 18$

T-110 sl 45

U-102 $\quad 159$

U-108 227

U-109 210

West Area

Non-complex

$\begin{array}{lll}\text { Total }= & 2426 & \text { (Kgal }\end{array}$

East \& West Non-complex Total = $4197 \mathrm{Kgal}$

Total SST Pumpable Liquid Waste $=$

- - Suspected to be Complex 
WHC-SD-W236A-ES-012

Revision 0

This page intentionally left blank. 